REVISTA DE DERECHO UNED, NÚM. 16, 2015

\title{
EL COMISARIO EN LAS PRIMERAS DILIGENCIAS DE INVESTIGACIÓN EN EL DELITO DE BIGAMIA. EL CASO DE MANUEL RIÑÓN DEL MOZO EN EL TRIBUNAL DE LA INQUISICIÓN DE CUENCA
}

\author{
THE COMMISSIONER IN THE FIRST FORMALITIES OF \\ INVESTIGATION IN THE CRIME OF BIGAMY. MANUEL RIÑÓN'S \\ CASE OF THE YOUNG BOY IN THE COURT OF THE \\ INQUISITION OF CUENCA
}

\section{Eulogio FERnÁndez CARRASCO}

Profesor Contratado Doctor del Departamento de Historia del derecho y de las Instituciones. Universidad Nacional de Educación a Distancia

Resumen: El Comisario es un oficial de la Inquisición, el cual representa a esa persona que goza de los privilegios y jurisdicción anexos al Santo Oficio y que se encuentra en las principales ciudades y casi con las misma competencias que el Inquisidor, excepto el emitir sentencias. De entre los requisitos exigidos al Comisario, podemos destacar los tener cuarenta años de y pertenecer al clero secular o regular. A la vez que debía ser un hombre prudente y ejemplar en costumbres. De entre sus funciones, cabe destacar, la de ser representantes del Inquisidor, recibir delaciones, acusaciones, citar a los testigos y delincuentes, detener, recibir declaraciones, torturar y encarcelar.

Abstract: The Commissioner is an official of the Inquisition, who represents this person who enjoys the privileges and jurisdiction annexes to the Holy Trade and who is in the principal cities and almost with same competitions that the Inquirer, except to issue judgments. Of between the requirements demanded from the Commissioner, we can emphasize them be forty years old of and belong to the secular or regular clergy. Simultaneously that had to be a prudent and exem- 
plary man in customs. Of between his functions, it is necessary to stand out, herd to be representatives of the Inquirer, receive delations, accusations, mention the witnesses and delinquents, stop, receive declarations, torture and to imprison.

Palabras clave: Inquisidor, Familiar, Comisario, Bigamia, Fiscal.

Keywords: Inquirer, Relative, Commissioner, Bigamy, District attorney.

Recepción original: 03/03/2015

Aceptación original: 31/03/2015

Sumario: I. Introducción. II. Las atribuciones del Comisario. III. Procedimiento de investigación en el delito de bigamia. IV. Examen del proceso de investigación. V. La delación. VI. Primera comisión de investigación al delator y testigos. VII. Declaraciones del delator y testigos. VII.A. El delator Santiago Antelo Coronel. VII.B. Testigo Eugenia López. VII.C. Testigo Josefa Cañas. VII.D. Testigo Tomás Borja Collado. VII.E. Testigo Concepción Antelo. VII.F. Testigo Juana Collado. VIII. Prueba documental. VIII.A. Cartas. VIII.B. Requisitoria. IX. Cumplimentación y credibilidad de las investigaciones. X. Recepción y traslado al promotor Fiscal. XI. Petición del Fiscal. XII. Segunda Comisión de investigación matrimonial. XIII. Investigación testifical. XIII.A. Testigo Gabriel José Gil. XIII.B. Testigo Joaquín Julián López. XIV. Conclusiones. XV. Bibliografía. XVI. Apéndice I. Cartilla de Comisarios de Cuenca.

\section{INTRODUCCIÓN}

Los episodios inquisitoriales conquenses constituyen un enorme laboratorio para investigar y poder sacar a la luz algunos de los episodios oscuros de la historia inquisitorial conquense.

En el proceso inquisitorial analizado, la delación fue la manera habitual que utilizó la Inquisición para condenar a los culpables de la práctica de doble matrimonio, en ellos se relata la observación de ciertas costumbres extrañas a los ojos de los denunciantes anónimos, que sirven como prueba del delito de herejía.

El delito de bigamia ${ }^{1}$, se encuentra dentro de los delitos del sexo, junto al incesto y la fornicación. La Iglesia, a través del Concilio de

\footnotetext{
${ }^{1}$ Según el Derecho Canónico, comete bigamia el sacerdote consagrado al servicio de Dios que contrae matrimonio, el casado que decide ordenarse sin el consentimiento de su propia mujer y el individuo que contrae matrimonio dos o más veces.
} 
Trento, intentó regular y controlar el tema del matrimonio. La Inquisición antigua o medieval no quiso entrar en esta materia y lo dejó en manos de los tribunales civiles. Es a partir de 1530, cuando la Inquisición se incorpora de pleno a contemplar el delito de bigamia y su castigo, debido todo ello a la gran cantidad de delitos que se producen a partir del Concilio de Trento. Pero es a partir del año de 1565 cuando la Inquisición castiga de forma rigurosa el delito de bigamia.

Es notorio que las delaciones quedaban sometidas a la calificación de los calificadores ${ }^{2}$, para que después de su estudio, se pronunciaran sobre si existía o no materia punible. En el caso que estudiamos sobre bigamia, en donde era necesaria la averiguación de lo sucedido sobre si era cierto o no, estas indagaciones no requerían demasiadas sutilezas a la hora de llevarlo a cabo.

La competencia sobre temas de bigamia ${ }^{3}$, correspondía tanto a los tribunales eclesiásticos como a los civiles, dando lugar a un constante conflicto de jurisdicciones, pues los tribunales civiles entraban a conocer de los daños ocasionados a la víctima, que generalmente era la mujer con motivo de sentirse engañada; en el orden eclesiástico, sobre el estudio de la validez o no del matrimonio y por último, que es el que aquí nos ocupa, en la averiguación sobre si la causa era motivo de ser considerada como herejía la vulneración del matrimonio en sí.

La documentación sobre la que se trabaja en este estudio, es el documento conservado en el Archivo Diocesano de Cuenca, en adelante ADC, Leg. 747C, n. ${ }^{\circ}$ 1806, con el título: Manuel Riñón, natural de Aguilar de Campos y vecino de Valladolid. Valladolid, a 1820. Bigamia. Incompleto. La traducción que hemos llevado a cabo se ha hecho con el objeto de ofrecer la mayor concisión y fidelidad documental y en ocasiones, se han usado anotaciones para el esclarecimiento de la corrupta y caprichosa paleografía y a lo se invita a que pueda ser corregida. Con este estudio, se pretende que más adelante se pueda investigar y mejorar el presente e interesante trabajo.

Comete bigamia el que contrae un segundo matrimonio sin estar disuelto legalmente el primero. Las penas impuestas por la Inquisición, consistían por lo general, en la salida en los Autos de Fe, portando el sambenito, soga al cuello, vela y coroza y acompañado de la pena de azotes con la obligación de abjurar o bien de levi o bien en forma de vehementi y como castigo muy grave, el sometimiento a galeras a remo $\mathrm{y}$ sin sueldo.

${ }^{2}$ En el periodo que estudiamos, normalmente lo ejercían fray Diego de Villena, junto con fray Gaspar Navarro.

${ }^{3}$ Sobre el delito de bigamia es imprescindible la obra de GACTO, E. «El delito de bigamia y la Inquisición española" y VVAA. Sexo barroco y otras transgresiones pre modernas, Madrid, 1990. 


\section{LAS ATRIBUCIONES DEL COMISARIO}

Las atribuciones de los Comisarios, estaban contempladas en las Instrucciones de Comisarios ${ }^{4}$. Entre las facultades de los Comisarios ${ }^{5}$, podemos destacar como la más importante, la de controlar el territorio a su cargo, siendo necesario poseer una gran capacidad y cierta posición eclesiástica y social. En la práctica eran los jefes inmediatos de los Familiares, seleccionándolos de entre los clérigos, teniendo mayor importancia que aquellos en las causas de fe. De entre sus misiones podemos destacar las siguientes: recibir denuncias, la substanciación de las causas de fe, la publicación de los edictos, la verificación de las genealogías de los pretendientes a cargos en el Tribunal. En zonas difíciles (puertos, fronteras), aumentaba su número como por ejemplo en la frontera de España con Francia donde se les encomendó la tarea de impedir el contrabando de armas y caballos. Cualquier persona podía acudir ante el Comisario del lugar para entregar

${ }^{4}$ Estas Instrucciones estaban hechas por el Inquisidor General. En ellas se contemplan las tareas de actuación que debían hacer, significando entre las más relevantes, su correspondencia con el tribunal del Santo Oficio, la forma de llevar a cabo los interrogatorios a los testigos y a los denunciantes, confeccionando los expedientes que contenían las declaraciones y diligencias. Otras de las funciones señaladas era la de nombrar ayudantes. Como misión fundamental, el Comisario, tenía la de informar al tribunal respecto a la vida y costumbres de las gentes que estaban dentro de su jurisdicción. En las mencionadas Instrucciones, se fijaba la forma de recibir las denuncias con facultad para ampliarlas y emplear cualquier medida que considerara oportuna, también recibía la de los testigos. Una vez hecho esto, remitían la información al tribunal con una valoración sobre la credibilidad de los delatores o testigos, valoración que podía influir en las decisiones del tribunal.

${ }^{5}$ Instrucciones y advertencia que para el acierto y buen despacho del Santo Oficio deben presentar los ministros Comisarios, y demás de él en los que se encargue, observándolas literalmente con las particularidades según la calidad del asunto, Zaragoza, imprenta viuda de Francisco Moreno. s/f.

Existen también las siguientes Instrucciones:

Instrucción que han de guardar los Comisarios del Santo Oficio de la Inquisición en las causas y negocios de fe, y los demás que se ofrecieren. ADC, Leg. 835, número 8204.

Instrucción y orden de procesar que han de guardar los Comisarios y Notarios del Santo Oficio de la Inquisición en las causas y negocios de fe, informaciones de limpieza de sangra y demás que se ofrecieran, Sevilla, Imprenta Mayor, 1778. Existe otra edición en Sevilla, Imprenta Real, 1815 en la BN. V. C.. ${ }^{2}$ 284-29 y R/61634.

Instrucción de Comisarios del Santo Oficio de la Inquisición. Instrucción que deben observar los Comisarios y Notarios del Santo Oficio de la Inquisición en el despacho de los negocios de fe y demás tocantes a su conocimiento, Madrid, Imprenta Real, 1816, en la biblioteca de la Academia de Jurisprudencia y Legislación, signatura $9 / 2331$.

Instrucción que han de guardar los Comisarios del Santo Oficio de la Inquisición, en las causas, y negocios de fe, y los demás que se ofrecieren, año 1820.

BN. VC/15125/14. 
una denuncia por escrito y ante Notario referente al delito de herejía. Éste procedía a las investigaciones citando a los testigos y siendo interrogados con arreglo a un formulario establecido. La información se enviaba al Tribunal. También podían detener a los sospechosos si existían abundantes pruebas o se sospechara que podían huir.

Además de las citadas, podemos señalar otras no menos importantes, como era la de torturar para arrancar las declaraciones, representar al Inquisidor, también podía recibir testimonios y confesiones, encarcelar y las no menos importantes como son las de investigar, ordenar la ejecución de prisiones, publicar Edictos de Fe, vigilar las entradas de libros y realizar informaciones de limpieza de sangre, la custodia de documentos ${ }^{6}$ y el cumplimiento y guarda y custodia de la Instrucciones de Comisarios ${ }^{7}$.

\section{PROCEDIMIENTO DE INVESTIGACIÓN EN EL DELITO DE BIGAMIA}

En las causas de doble matrimonio, recibía el Comisario la delación, e inmediatamente, la trasladaba al Tribunal. A continuación recibía de éste, las instrucciones oportunas para llevar a cabo las diligencias pertinentes, tales como ratificar al delator, compulsar la partida o partidas de matrimonio, examinar al párroco o al ministro asistente a su celebración, interrogar a los testigos presenciales y en defecto de estos últimos, de personas en quienes se pudieran confiar sus opiniones y testificaciones. Por último, compulsar si existieran, las partidas de los hijos. El encargado de llevar a cabo la averiguación de los hechos, ya hemos dicho que era el Comisario del Santo Oficio que residía en el lugar de los hechos, el cual, recibía un nombramien-

${ }^{6}$ Instrucción 1816. I. Custodia de papeles. El Comisario reservará con toda seguridad las comisiones, despachos y órdenes del Tribunal, sin confiarlas al Notario, para que las retenga en su poder. A continuación de cada despacho o pliego en que el Tribunal le confiera algún encargo extenderá la declaración, respuesta a informe que se le hubiese mandado; y sin quedarse con copia, borrador o noticia de lo que haya actuado, lo devolverá y remitirá todo al Tribunal, escribiendo carta separada respecto de cada expediente, para evitar confusión. En todos los pliegos de oficio que el Comisario dirija al Tribunal deberá poner en la cubierta: Al Santo Oficio de la Inquisición de..........abajo el que fuere.

${ }^{7}$ Instrucción 1816. X. Custodia de esta Instrucción sobre el modo de evacuar las comisiones. Los Comisarios, Notarios, Familiares y demás Ministros conservarán la presente instrucción con toda seguridad y secreto; se sujetarán a ella, y observarán sus fórmulas con la mayor exactitud para desempeñar con acierto las comisiones que merecieren el Tribunal, debiendo consultarle en los casos dudosos sobre las diligencias más conformes a disposiciones de derecho; e igualmente sobre todo negocio grave por su naturaleza o por las circunstancias de las personas en él complicadas. 


\section{Eulogio FERnández CARRAsco}

to o comisión para llevarlo a cabo y para el caso de que éste se hallase ausente del lugar, se nombraba al párroco. Para ello, los Inquisidores, les advertían de la obligación que tenían de llevarlo a cabo de acuerdo con la Instrucción que tenían los Comisarios. Concretamente, estaba regulado en los artículos 13, 18, 19 y 23 especialmente.

Nos los Inquisidores apostólicos contra la herética pravedad y apostasía en las ciudades y obispado de Cuenca, Sigüenza, Priorato de Uclés y su partido, por autoridad apostólica y real. Hacemos saber a vos don Juan Norberto Cantero, nuestro Comisario en esta ciudad... os encargamos que luego que recibáis esta nuestra comisión y acompañado del que ha hecho de Notario en las anteriores diligencias... pues para todo ello lo haréis y de presente os damos esta nuestra comisión en forma. En la Inquisición de Cuenca y marzo, seis de 1820. Licenciado don Miguel de Villar y Solera. Ignacio Rodríguez de Fonseca, secretario ${ }^{8}$.

El nombramiento de comisionado que se hacía al Comisario del lugar, era obligatorio para éste, debiendo constar tal aceptación ${ }^{9}$. Jun-

${ }^{8}$ ADC, leg. 747C, n. ${ }^{\circ}$ 1806, f. 20r. Manuel Riñón, natural de Aguilar de Campos y vecino de Valladolid. Valladolid, a 1820. Bigamia. Incompleto.

AHN. Inquisición. Leg. 2601. Consejo de Inquisición. Año de 1814, folio 8. Expediente sobre la reedificación del tribunal de la Inquisición de Cuenca. Número de ministros existentes y muertos y recuperación de sus fincas y rentas. Ministros. D. Ignacio Rodríguez de Fonseca, juró el empleo de Secretario del Secreto que sirve el día 2 de enero de 1793.

${ }^{9}$ Diligencia de aceptación de la comisión que da el Santo Oficio y juramento de fidelidad y secreto que se debe hacer por los comisionados y personas que hacen de Notarios si no fueren ministros.

Luego que reciba la comisión del Santo Oficio la persona a quien se cometa la práctica de alguna diligencia antes de pasar a ponerla en ejecución debe prestar juramento de que hará con fidelidad su encargo, y guardará secreto de todo lo que por esta razón supiere o entendiere; el cual y la aceptación de la comisión que se le da, ha de constar por diligencia al pie del despacho y se extenderá en la forma siguiente: Yo D. N. de N., Presbítero, Religioso, o lo que fuere, acepto y estoy pronto a cumplir lo que por el Tribunal de la Santa Inquisición se manda en el despacho antecedente; y hago juramento según mi estado, puesta la mano en mi pecho y de cumplir bien y fielmente lo que por él se me ordena, y guardar secreto de cuanto en su razón supiere y entendiere, y no lo comunicará nadie y para que conste lo firmo en........... t......... del mes de t...........año de t..........D. N. de N.

Si la comisión se ampliase a que se practiquen las diligencias que se encargan ante otra persona que haga de Notario, si la tal persona fuese Ministro del Santo Oficio, se pasa inmediatamente al examen del testigo o diligencia que se manda, acompañado de dicho Ministro para que dé fe y la autorice.

Si la tal persona que ha de hacer de Notario no fuese Ministro del Santo Oficio, ante todas cosas, y sin que entienda nada del asunto, debe hacer juramento de fidelidad y secreto y lo mismo que el Comisionado, que también debe constar; y la diligencia de juramento de este se extiende en uno de los modos siguientes, según el estado de la persona nombrada por Notario.

Si fuese secular. En la ciudad, villa o lugar de N. á t. del mes de t. año de t..........Yo D. N. de N., Cura, o lo que fuere, comisionado por el Santo Oficio de la Inquisición, para la práctica de las diligencias del despacho antecedente, hice saber a 
to al Comisario, el Inquisidor, mandaba a un Familiar o Notario de la Inquisición para que le auxiliara en sus tareas.

En la ciudad de Cuenca a 20 días del mes de enero de 1820, el padre don Juan Norberto Cantero, Comisario del Santo Oficio de la Inquisición de dicha ciudad, hizo comparecer ante sí al presbitero don Julián Ruiz vecino de ella de quien recibió juramento que hizo por Dios Nuestro Señor y una señal de la cruz bajo del cual ofreció guardar secreto y contribuir en cuanto pudiese al desempeño de la comisión sin manifestar cosa alguna directa ni indirectamente so pena de perjurio y demás del arbitrio del tribunal y porque así lo cumplirá sin contravenir en manera alguna a lo que deja dicho bajo su juramento en el cual dijo se afirmaba y ratificaba caso necesario, lo firmó de su puño y nombre en la nominada ciudad, día, mes y año arriba dichos. El padre Juan Norberto Cantero. Julián Ruízio.

El medio que se utilizaba para llevar a cabo tal nombramiento y comisión, era el poder por escrito. Junto al poder, se le acompañaba un pliego con una serie de preguntas que debía realizar el Comisario junto a la forma de realizarlas y la persona a quien iban dirigidas las preguntas. Las tareas que debía llevar a cabo el Comisario, consistían en líneas generales, en las siguientes: visita al párroco donde se celebró el matrimonio para comprobación de la veracidad del mismo; llevar a cabo la inspección de los libros parroquiales y de forma señalada, la comprobación de la identidad de la persona a la que se le imputa el delito; la fecha de celebración y el nombre del otro contrayente; lugar de residencias y la identificación del lugar de nacimiento de los contrayentes. Otro de los papeles fundamentales del Comisario, era, la averiguación del nombre y lugar de nacimiento de los testigos. Éstos, eran llamados posteriormente a declarar, debiendo ratificar lo declarado y decir lo que habían visto en la celebración del matrimonio y así poder averiguar si se producía alguna mentira en sus declaraciones. Esta confesión y la posterior ratificación testifical, se llevaba a cabo en presencia de dos testigos considerados buenos cristianos. La declaración del párroco, generalmente se hacía en la parroquia de la que era titular; pero a veces se realizaba en la sede del tribunal en presencia de los Inquisidores.

D. N. de N. se hallaba nombrado por dicho Santo Oficio para actuar conmigo como Notario en ciertas diligencias, y que para ello tenía que hacer ante todas cosas juramento de fidelidad y secreto; y habiéndolo oído y entendido, dijo estaba pronto a cumplirlo y en su consecuencia inmediatamente le recibí juramento, que hizo a Dios nuestro Señor y una señal de cruz, de hacer bien y fielmente su oficio, y guardar secreto en todo lo que oyere y entendiere; y lo firmó ante mí. Aquí la firma del Comisionado. Aquí la del Notario.

${ }^{10}$ ADC, leg. 747C, n. ${ }^{\circ} 1806$, f. 5. 
Hacemos saber a vos don Juan Norberto Cantero, nuestro Comisario en esta ciudad, que habiendo necesidad de compulsar la partida de matrimonio que celebró en la parroquial de San Gil de esta ciudad en 4 de agosto del año pasado de 1810, Manuel Riñón, natural de Aguilar de Campos con Juana Collado, que lo es de esta de Cuenca, os encargamos que procederéis bajo juramento de decir verdad y guardar secreto, con separación y en pliego aparte al teniente de cura de dicha parroquial, don Juan Bautista Saiz, acerca de si asistió a la celebración de dicho matrimonio el día, mes y año en que ocurrió y quienes fueron testigos. Bajo igual juramento, con separación y en pliego aparte, serán examinados don Joaquín López, clérigo tonsurado y Deogracias López que se dan por testigos de haber presenciado el acto, según se previene en la Instrucción de Comisario al número 11 y concluidas estas declaraciones que firmarán lo que supieren, dejando mediar como dos o tres días, la ratificaréis ad perpetuam con arreglo a los números 18 y 19 de dicha Instrucción. En la Inquisición de Cuenca y marzo, seis de 1820. Licenciado don Miguel de Villar y Solera. Ignacio Rodríguez de Fonseca, secretario ${ }^{11}$.

Una vez recabados todos los datos de averiguación sobre la celebración o no del matrimonio y hechos acaecidos, se remitía en pieza separada al tribunal que lo había ordenado para su inclusión en el proceso, proceso que a veces podía durar años. Si el resultado era positivo y la denuncia verdadera, el acusado era obligado a ingresar en prisión.

Hacemos saber a vos don Juan Norberto Cantero, nuestro Comisario en esta ciudad... con separación y en pliego aparte. En la Inquisición de Cuenca y marzo, seis de $1820^{12}$.

Los fraudes que se llevaban cabo en estas conductas, consistían en actuaciones como eran la de emplear nombres falsos, declarar lugares de nacimientos artificiales o lo más comúnmente empleado, la declaración del estado de viudedad del futuro contrayente, el cual ya estaba casado con anterioridad. Por lo general, solían celebrar matrimonio lejos de los lugares de nacimiento, en donde el acusado no era conocido.

El bígamo, actuaba con una conducta delictiva, pues era sabedor de que su actuación no era lícita y en donde el error doctrinal no se produce. Son conocedores del pecado que están llevando a cabo y aun así lo llevan a término. La Inquisición pretende con esta persecución y castigo, averiguar si ha existido o no la negación del sacramento del matrimonio y su consiguiente indisolubilidad. De los procesos que hemos estudiado existentes en el Tribunal de Cuenca, hemos detectado que en cuanto al sexo, el que cometía tales delitos de bigamia, so-

\footnotetext{
11 Íbid., f. 20v.

12 Íbid., f. 21.
} 
EL COMISARIO EN LAS PRIMERAS DILIGENCIAS DE INVESTIGACIÓN...

lía ser el varón, siendo inferior el número de mujeres que perpetraban tal delito.

\section{EXAMEN DEL PROCESO DE INVESTIGACIÓN}

Pasemos a explorar el proceso inquisitorial seguido por el Santo Oficio de Cuenca en 1820 contra un vecino de Valladolid, natural de Aguilar de Campos, llamado Manuel Riñón, el cual es acusado de bigamia.

Estas diligencias se extienden en 33 folios en papel de que consta este cuadernillo, los cuales se encuentran cosidos por su lateral, teniendo las mismas características diplomáticas paleográficas todos los folios. Además está inserta la carta autógrafa de la delación escrita en papel por Santiago Antelo Coronel, Alguacil mayor y que también está cosida al resto del expediente, todo ello se halla en buen estado de conservación.

\section{LA DELACIÓN}

En cuanto al estudio de este proceso significaremos que, como es lógico, se inició por la delación ${ }^{13}$ del ya citado Santiago Antelo Coronel ${ }^{14}$, quien en una carta fechada el 14 de enero de 1820 y recibida el día 15 de enero en el tribunal de la Inquisición de Cuenca, siendo Inquisidores Miguel de Villar y Solera y Blas Manuel Sánchez Vallés, la cual él mismo firma y rubrica, donde expone que en la noche del cinco de enero, habiendo ido a su casa de visita el canónigo García con su criado Tomás, este último, se quedó en la cocina y le dijo que había visto a su padrastro, que era militar, el cual le preguntó al dicho Tomás que donde estaba el estanco, a lo que Tomás respondió ¿pero es

${ }^{13}$ Instrucción 1816. Para recibir delaciones. El delator o testigo citado o presentado debe ser examinado separadamente, y el Comisario ha de tomar las precauciones más prudentes para que ninguna persona extraña pueda percibir o entender lo que se trata. Toda declaración debe principiar en pliego separado, y el testigo debe prestar antes juramento de que guardará secreto, y dirá verdad en cuanto supiere y fuere preguntado, bajo la pena de perjuro, y otras a disposición del Tribunal.

Si fuere de doble matrimonio. Manifestará el delator cómo lo sabe, los nombres de los casados, los pueblos o parroquias en que contrajeron matrimonio y en qué tiempo, si viven, donde residen; o si murió alguno de ellos cuanto tiempo hace y en dónde; si tuvieron hijos, cuántos y cómo se llaman.

${ }^{14}$ ADC, leg. 682 B (38), n. ${ }^{\circ}$ 614. Informe sobre Santiago Antelo y Coronel, alguacil mayor electo de esta Inquisición. Se le dispensaron las pruebas respecto a que están calificados sus padres. Cuenca, 1808. 
vuestra merced? a lo que contestó el preguntado, ¿acaso me conoces? ¿De dónde me conoces? y dicho Tomás respondió, ¡ojalá no hubiera conocido a vuestra merced!

En la delación se recoge también que el dicho Tomás, le había confesado que su madre le había comunicado que su padrastro había estado en casa. Asimismo, se recoge el testimonio de Josefa Cañas, que manifestó que el día 4 los vio marchar juntos y que había estado el padre de Tomás en esta ciudad como unos cuatro días. La citada Josefa Cañas sigue declarando, que estando viviendo en casa del delator, no recordaba esto, pero si hacía memoria de que le dijo Tomás que hubiera querido ser soldado por su primo.

Igualmente, Eugenia López, la criada del delator, le dijo a Tomás hijo, que sabía que su padrastro estaba casado también con otra mujer, a lo que sonrió el hijo y dijo que eso ya se sabría. El delator continua investigando por su cuenta y preguntó de nuevo a la expresada Eugenia que si había oído decir que estaba casado con otra el padrastro de dicho Tomás, respondiendo que lo había oído antes de entrar a servir en su casa, pero no recordaba quien se lo había dicho. Sin embargo si recordaba, que el referido Tomás, le confesó que su padrastro le dijo una vez que se fuera con él, que creía ella que sería para servir al rey, y él le dijo que no le volvería a engañar más veces.

A preguntas del delator que hizo a su propia hermana, le dijo ésta, que había oído que hablando de las cosas que habían ocurrido con motivo de este incidente, que la madre del dicho Tomás se casó con un soldado y se fue con él, pero que más tarde se volvió a Cuenca, diciendo que se había encontrado con que estaba casado con otra el dicho Tomás, del cual decía que era soldado y que quizás tuviera la graduación de sargento ${ }^{15}$.

\section{PRIMERA COMISIÓN DE INVESTIGACIÓN AL DELATOR Y TESTIGOS}

Cuando esta carta delación es leída por el Tribunal de Cuenca, se ordena por éste, que sea librada comisión para el reconocimiento y examen según estilo, tanto del delator como de los testigos ${ }^{16}$. Poste-

${ }^{15}$ ADC, leg. 747 C, n. ${ }^{\circ} 1806$, ff. 1-3.

${ }^{16}$ Instrucción 1816. IV. Cuidado del Comisario en la forma de preguntar. El Comisario debe ser muy detenido y meditar mucho el tenor de las preguntas, para evitar que estas sean viciosas, y que entienda o presuma el testigo lo que otros han declarado. No debe manifestar los nombres de los reos, ni otros testigos, aunque los indique el que declara y por el peligro de que pueda prevenir y acomodar sus respuestas. Esta 
riormente, se redacta un auto de citación con fecha de 19 de enero de 1820 por parte del Inquisidor, el licenciado don Miguel de Villar y Solera y el secretario Ignacio Rodríguez de Fonseca ${ }^{17}$, llamando al delator Santiago Antelo y a los testigos Josefa López, Josefa Cañas y Tomás Borja, para que declararan, debiendo hacerlo en pliegos separados cada uno de ellos.

Los Inquisidores notifican al Comisario Juan Norberto Cantero ${ }^{18}$, para hacerle saber que en el Santo Oficio se había recibido una delación que estaba escrita y firmada por el Alguacil mayor Santiago Antelo Coronel y ya que era necesario que la reconociera, según práctica y estilo del Santo Oficio, se le encargó por auto, que en vista de esa comunicación y acompañado de un licenciado a su entera satisfacción, para que actuara en funciones de Notario y que tras hacer constar por escrito en las diligencias, la prestación de juramento y la promesa de guardar secreto ${ }^{19}$ de todo lo actuado, hicieran comparecer ante ellos de forma secreta y por separado a las siguientes personas:

Como primera medida, debía comparecer el delator Santiago Antelo Coronel y que tras recibirle juramento de decir verdad, debería reconocer su carta delación con arreglo a los números 23 y siguientes

cautela es muy propia del Santo Oficio, que solo pretende indagar la verdad, y deducir generosa y noblemente de cada testigo lo que por sí sabe y entiende o ha oído de la persona u objeto sobre que recae su declaración. Toda pregunta que se hace al testigo dará principio en renglón diferente; y lo mismo ha de ejecutarse con su respuesta: debe además estamparse con las mismas voces y materiales palabras que profiera el testigo, por blasfemas, hereticales, indecentes o deshonestas que sean. y sin la menor alteración; antes bien con sujeción a ellas deberá hacer las preguntas o repreguntas que estimare conducentes para averiguar la verdad y verificar la identidad del caso.

${ }^{17}$ Miembro y vocal de la Junta Suprema de Gobierno de Cuenca junto a Santiago Antelo Coronel.

${ }^{18}$ Perteneciente a la Congregación de San Felipe Neri del obispado de Cuenca según Bibliografía de religión, Madrid, 1827, p. 350.

${ }^{19}$ Instrucción 1816. I. Secreto. El fiel desempeño de las obligaciones propias de los Ministros del Santo Oficio de Inquisición en la práctica de los asuntos que se cometan a su cuidado y diligencia consiste principalmente en el secreto. Debe este guardarse con todo rigor, para cumplir con la estrecha obligación del juramento que prestaron al tiempo que fueron admitidos a sus respectivos destinos. El secreto no se ciñe solamente a las causas de fe, sino que se extiende también a todos los demás objetos de la jurisdicción del Tribunal, aunque sean de naturaleza de los que se llaman públicos. Cualquiera de los Comisarios, Notarios, Familiares, que viole o quebrante tan importante y precisa obligación incurre en las graves penas, así canónicas como civiles, establecidas por Derecho y Cartas Acordadas de los Señores Inquisidores Generales y Consejo; y el Tribunal procederá irremisiblemente a su declaración e imposición contra los reos de este delito para su digno castigo y justo temor de los demás Ministros. 
de la Instrucción de Comisarios y que una vez hecho este reconocimiento, se le obligara a firmarlo.

Acto seguido, también de forma separada y en pliego aparte, con la obligación de recibirle juramento de decir verdad y guardar secreto $^{20}$, debería proceder al examen de la testigo presencial Josefa de Cañas, acerca de lo manifestado en la referida delación, bajo el método que prescribía dicha Instrucción en sus números 3 y siguientes, haciéndole las preguntas y repreguntas que se estimaran convenientes en averiguación de la verdad. Una vez recibida la declaración, la firmaría en el caso que supiese escribir.

Posteriormente se procedería por parte del Comisario, al examen de Eugenia López bajo igual juramento, de forma separada y en pliego aparte, sobre lo que sabía la citada, en cuanto así lo tenía delatado respecto a que estaba casado con dos mujeres el denunciado Tomás Riñón y de la misma forma que declarara de donde lo sabía y quién se lo había dicho. Recibida la declaración tendría que firmarla si supiera hacerlo.

A continuación, debería proceder al examen de Tomás, el cual era tenido por hijastro del delatado, haciéndolo de la misma forma en cuanto al juramento y con separación y en pliego aparte y todo ello valiéndose del mismo método que se le había prescrito para el examen de las anteriores. De forma específica, tenía que confesar el nombre, apellido, naturaleza, ciudad y señas personales del delatado, en qué regimiento había servido y en el que servía en ese momento, si era cierto que estaba casado con su madre, cuándo llevó a cabo el matrimonio y ante qué párroco lo hizo. También debía responder sobre si sabía de donde era natural su primera mujer y como se llamaba y quién se lo había dicho. Además se facultaba al Comisario para hacerle las demás preguntas y repreguntas que estimara por conveniente en aras de la averiguación de la verdad. Una vez concluida la declaración, debería ser firmada.

Concluidas estas declaraciones, el Comisario procedería al examen de otras personas que figuraran en la delación y las que pudieran surgir por razón de la investigación, haciéndolo también de forma

${ }^{20}$ Instrucción 1816. III. Juramento de testigo o delator. El delator o testigo citado o presentado debe ser examinado separadamente, y el Comisario ha de tomar antes las precauciones más prudentes para que ninguna persona extraña pueda percibir o entender lo que se trata. Toda declaración debe principiar en pliego separado; y el testigo debe prestar antes juramento de que guardará secreto y dirá verdad en cuanto supiere si fuere preguntado, bajo la pena de perjuro, y otras a disposición del Tribunal. 
separada y en pliego aparte y todo ello bajo igual juramento según el método que iban expresados. Una vez evacuados los trámites y tras el transcurso de dos o tres días, correspondía al Comisario ratificarlos ad perpetuam bajo el método que prescribía la citada Instrucción en sus números 18 y 19. Y una vez hecho todo esto, tendría que remitirlos al Tribunal con el parecer suyo, sobre la fe y crédito que le habían merecido el delator y los testigos en sus declaraciones. Este último apunte, y en relación al estudio que presentamos, es donde estriba la importancia que adquiere el Comisario y la trascendencia que tiene su valoración, ya que según ésta, podía influir en el desarrollo de la condena o no del acusado ${ }^{21}$.

\section{DECLARACIONES DEL DELATOR Y TESTIGOS}

El delator y los testigos que hubiese, debían ser examinados por separado, debiendo el Comisario, hacer todo lo posible para que ningún vecino u otra persona, pudiera percibir de qué se trataba el asunto. Toda declaración, debería comenzar en pliego separado, debiendo el testigo, antes de nada, hacer juramento de guardar secreto y decir verdad de lo que se le preguntara, bajo la pena de perjuro.

$\mathrm{Al}$ delator se le exigía que manifestara cómo sabía la existencia del doble matrimonio, los nombres de los esposos, los lugares o pueblos en donde se había llevado acabo el matrimonio y cuando se llevó a cabo. Igualmente se le preguntaba si sabía si vivían todavía los contrayentes o murió alguno de ellos y si sabía en qué lugar habían fallecido y por último si sabía si tuvieron hijos, cuántos y como se llamaban.

Todas las preguntas dirigidas al testigo, debían ser claras y no estar viciadas para que el testigo entendiese claramente lo que se le preguntara. Tampoco podía el Comisario manifestar nombre alguno, para que el testigo no pudiera argumentar defensa en base a su conocimiento de los hechos o testigos. Todas las preguntas debían ir en renglones separados al igual que las respuestas, recogiendo fielmente toda palabra, aunque resultase malsonante o fuesen blasfemias o indecencias. Al margen de cada declaración, debía exponer el Comisario, su juicio acerca de la credibilidad que merecía el testigo que acababa de declarar o del delator. Separadamente debía hacer un informe de la vida, costumbres y opinión pública sobre la persona declarada, ayudándose de persona timoratas y prudentes imparciales, tomando las cautelas pertinentes, para no ser descubierto sobre sus propósitos.

${ }^{21}$ ADC, leg. 747C, n. ${ }^{\circ} 1806$, ff. 4r-4v. 


\section{VII.A. El delator}

Llegado el día 25 de enero de 1820, se produce en Cuenca ante Juan Norberto Cantero, Comisario del Santo Oficio de dicha ciudad, acompañado del Notario ${ }^{22}$ Julián Ruiz, la comparecencia con motivo de haber sido llamado, de Santiago Antelo Coronel $^{23}$, Alguacil mayor de la Santa Inquisición y vecino de la citada ciudad, al que se le obligó a jurar en forma y que diría la verdad prometiendo guardar secreto.

Fue preguntado si sabía o presumía la causa por la que había sido llamado y dijo, que presumía que sería para saber de la certeza de un oficio que dirigió al tribunal días pasados del mes de enero, pasando a exponer de forma sucinta su contenido. Le fue exhibido el oficio y dijo ser el mismo que había dirigido a dicho tribunal y que estaba escrito de su puño y que no tenía que añadir, quitar, ni enmendar cosa alguna, por ser lo único que le parecía. A continuación, manifestó,

${ }^{22}$ Instrucción 1816. XI. Sobre el nombramiento de Notario y sus circunstancias. Cuando el Comisario reciba despachos del Tribunal para la ejecución de algún asunto, sea o no de fe, observará si se le señala Notario que tenga este título del Santo Oficio, y le requerirá para que cumpla puntualmente lo que se le ordena. Si se le da facultad para la elección de Notario, será muy conducente la haga de persona calificada y si no la hubiese, requerirá a la que merezca esta confianza por su probidad, secreto y buena opinión; si no aceptase este encargo, especificará los motivos y causas que para ello tuviese, firmando esta diligencia; y el Comisario las manifestará muy circunstanciadas y con toda exactitud al Tribunal para que provea del remedio necesario.

Diligencia de aceptación de la comisión que da el Santo Oficio. Si se diese facultad al Comisionado para que a su arbitrio nombre algún secular que haga de Notario en las diligencias, pondrá la de la aceptación y juramento de la tal persona en los mismos términos que la antecedente con solo la diferencia de que en lugar de la cláusula que dice: le hice saber se hallaba nombrado por dicho Santo Oficio, pondrá: haberle yo nombrado para actuar como Notario en él según virtud de la facultad con que para ello me hallo y sigue lo demás como en el número antecedente y que para ello tenía que hacer ante todas cosas juramento.

Si fuere Eclesiástico, el que, nombrare el Tribunal o el Comisionado. En el caso de darle facultad para ello, para hacer de Notario entonces no se ponen las dos diligencias separadas que van prevenidas de Comisionado y Notario, sino que en una se evacúa todo, y es en /a forma siguiente:

En la ciudad, villa o lugar de N. a t..........de tal mes..........Habiendo recibido la comisión antecedente de los señores Inquisidores del Santo Tribunal de N., y estando yo D. N. de N. pronto a su ejecución, lo hice saber a D. N. de N. Presbítero, nombrado para hacer de Notario en las diligencias que en ella se encargan, o que nombré, si fuere el Comisionado el que lo nombrare; y estando asimismo pronto para hacer lo que se manda, nos recibimos recíprocamente juramento según nuestro estado y puesta la mano en el pecho, de hacer bien y legalmente lo que se nos ordena, y guardar secreto de lo que oyéremos y entendiéremos en este asunto; y lo firmamos.

Aquí la firma del Comisionado. Aquí la del que ha de hacer de Notario.

${ }^{23}$ Miembro como vocal de la Junta Suprema de Gobierno de Cuenca junto a Ignacio Rodríguez Fonseca. 
que también Juliana Sánchez, criada suya, se hallaba presente y alguno que otro de la casa que pudiera entrar o salir. Dio palabra de que era la verdad lo que declaraba en base al juramento que tenía hecho. Y una vez leída la misma, dijo que estaba bien escrita y que lo manifestado y escrito, no lo decía por odio, sino por descargo de su conciencia. Terminó prometiendo guardar secreto y lo firmó.

\section{VII.B. Testigo Eugenia López}

La declaración de Eugenia López se produce en Cuenca el día 26 de enero de 1820, haciéndolo en la sesión de la mañana. Compareció con motivo de haber sido llamada y juró en forma que diría verdad y guardar secreto de todo, y dijo llamarse Eugenia López, de estado doncella, hija de Juan Antonio López, difunto, y de Isabel Velasco, vecinos de la villa de Orea y que estaba sirviendo en casa de don Santiago Antelo Coronel, vecino de Cuenca y terminó reconociendo tener 19 años.

Fue preguntada si sabía o presumía la causa por la que había sido llamada y dijo que ni sabía ni presumía la causa. Sobre la pregunta de si sabía o había oído decir que alguna persona hubiera contraído dos matrimonios viviendo la mujer del primero, dijo que en el año de 1819, oyó decir, aunque no sabía a quién ni en donde, que el marido de la que en la ciudad de Cuenca llaman por mote la Chichada, estaba casado con dos mujeres y que anteriormente había oído en casa de su amo, al criado del canónigo García, el llamado Tomás hijo de dicha Chichada, que había visto en la calle a su padrastro. Por otro lado, la declarante manifestó que se decía por ahí, que el tal Tomás Riñón, se había casado por dos veces, al igual que otra criada de la misma casa, llamada Josefa de Cañas, le preguntó a Tomás que si era verdad, a lo que respondió éste que eso no se sabía y que ya se vería.

También, otra noche, estando en conversación con Tomas le volvió a preguntar la dicha Josefa si era cierto que su padrastro tenía dos mujeres, a lo que éste contestó que no lo sabía, pero que le había dicho a su madre que tenía 2 hijas de otra mujer y que sin embargo no sabía si estaba o no casado con ella. Termina diciendo, que en la conversación estaban presentes además de la declarante, sus compañeras Josefa de Cañas y Juliana López. Cuando se le pregunta si sabía cómo se llama el padrastro de Tomás, confesó que no sabía cómo se llamaba, como tampoco de donde era natural, y que desconocía quien era la otra mujer. 


\section{VII.C. Testigo Josefa Cañas}

Josefa Cañas, declaró en Cuenca el día 30 de enero de 1820 en la sesión de la tarde, ante Juan Norberto Cantero, Comisario del Santo Oficio de ella, compareció con motivo de ser llamada y en la que prestó juramento en forma, prometiendo decir la verdad. Declaró que era doncella, natural de la villa de Montalvo, y que en esos momentos estaba sirviendo en Cuenca, en casa de don Santiago Antelo, añadiendo que tenía 44 años de edad.

Cuando se le pregunta si sabía o presumía cual era la causa por la que había sido llamada a declarar, contestó que presumía pudiera ser para que se supiera lo que oyó de una conversación que se produjo en casa de su amo algunos días antes de esta declaración. Ante lo cual, fue conminada a que contase lo que había oído en tal conversación y empezó a narrar, que una noche que estaba de visita en casa de su amo el canónigo García, el criado de éste, llamado Tomás, se fue a la cocina y dijo que subiendo por San Felipe se encontró con una persona y le preguntó que dónde estaba el estanco, a lo cual, Tomás se encaró con el que le preguntaba recomendándole que mirase por ahí. Al estar enfrente uno de otro, la persona mayor le dijo al joven, ¿oye tú me conoces? ¿Quién eres tú? a lo que el joven contestó, yo soy Tomás.

La declarante también oyó decir al dicho Tomás, que aquel hombre era su padrastro. Igualmente escuchó decir a otra criada llamada Eugenia, que le preguntaba a dicho Tomás que si era cierto que su padrastro estaba casado con dos mujeres, a lo que respondió Tomás que eso ya se sabría. Completó su declaración diciendo que en la conversación estaban presentes la declarante y las otras dos criadas, llamadas Eugenia y Juliana; pero que después hicieron conversación con su ama doña Concepción Antelo y le refirieron todo lo que había pasado y dicha señora dijo que también había oído que el padrastro del Tomás estaba casado dos veces, a lo que la declarante dijo que creía que la madre del Tomás era la primera con quien se había casado el acusado y contestaron, aunque no se acordaba quién fue, que ya estaba casado por allá cuando se casó en Cuenca.

\section{VII.D. Testigo Tomás Borja Collado}

Tomás Borja, presta declaración en Cuenca el 10 de febrero de 1820 en sesión matinal ante el padre Juan Norberto Cantero, Comisario del Santo Oficio de ella, habiendo comparecido por haber sido llamado a declarar. En la misma sesión juró en forma prometiendo 
que diría la verdad. Declaró que estaba casado, que era vecino de Cuenca y dijo tener 21 o 22 años poco más o menos.

Cuando es preguntado si sabía o presumía la causa por la que había sido llamado, contestó que no lo sabía ni presumía. Al preguntarle de nuevo sobre si sabía o había oído decir de alguna persona que hubiera contraído un segundo matrimonio, viviendo la mujer del primero, manifestó que lo que había oído decir era, que su padrastro Manuel Riñón, sargento retirado del batallón de Mallorca, natural de Aguilar de Campos y residente en Valladolid. A continuación empezó a explicar los datos personales de su padrastro, dijo que era de estatura como de unos cinco pies, pelo y cejas negros, y cortados los pies en uno, solo los dedos y en el otro, algo más Y que al presente se hallaba casado en Cuenca en la parroquia de San Gil, con Juana Collado, su madre, vecina de Cuenca. Amplió su declaración en el sentido de que estaba casado con otra cuando celebró el matrimonio con su madre y que también había oído decir a su madre que su padrastro tenía dos hijos de la otra mujer, pero que sin embargo, no sabía el testigo, si estaba casado o no con ella, sin embargo ocurrió que a primeros de 1820, le había dicho su madre que había estado en casa, en su compañía como unos cinco o seis días. Asimismo dijo el testigo que haría como unos cuatro años, que el señor Provisor de Cuenca, con objeto de hacer las averiguaciones pertinentes sobre si era cierto o no, en lo que se decía de su padrastro, ofició al Provisor de Valladolid una requisitoria para averiguar el asunto del doble matrimonio de su padrastro y que no sabía que hubiera habido contestación sobre ello.

\section{VII.E. Testigo Concepción Antelo}

Concepción Antelo, testificó en Cuenca el 20 de febrero de 1820 en la sesión de tarde, ante Juan Norberto Cantero, presbítero y Comisario del Santo Oficio de ella. Compareció por haber sido llamada y juró en forma que diría la verdad sobre todo lo que se le preguntara, reconoció que era viuda, vecina de Cuenca y tener 43 años. Al ser preguntada si sabía o presumía la causa por la que había sido llamada, contestó en sentido negativo a las dos preguntas. Sobre la pregunta de si sabía o había oído decir a alguien que una persona había contraído dos matrimonios, cuando todavía, vivía la mujer del primero, respondió afirmativamente que sí lo había oído decir, pero que no se acordaba de quien, que el marido de la que por mote se llamaba Chichada, estaba casado por dos veces y que esto lo supieron por haber ido la 
Chichada con él a Madrid y fue allí, donde se encontró que tenía otra mujer por cuya razón tuvo que volver a Cuenca y que aunque no estaba segura a quien lo había oído, cree que fue a las criadas que entonces tenía, por cuya razón no le dio el mayor crédito.

\section{VII.F. Testigo Juana Collado}

La primera declaración que hace Juana Collado, mujer del denunciado Manuel Riñón, se produce en Cuenca el 15 de febrero de 1820 en sesión de tarde, ante el padre Juan Norberto Cantero, Comisario del Santo Oficio. Fue llamada para comparecer y una vez hecho esto, juró decir la verdad y dijo estar casada, tener 40 años de edad y ser natural y vecina de Cuenca.

Cuando se le pregunta que si sabía o presumía la causa por la que había sido llamada, contestó en sentido negativo a las dos preguntas. En relación a que si sabía o había oído decir que alguna persona había contraído dos matrimonios sin estar fallecida la primera mujer, describió con todo detalle las circunstancias del caso e hizo una breve descripción física de su esposo, explicó que había oído decir que su marido Manuel Riñón, sargento retirado del regimiento de Mallorca, de estatura como de unos 5 pies, pelo y cejas castaños, ojos de color negros y que tenía dos medios pies cortados.

Continuó diciendo que en ese momento, su marido residía en Valladolid y que estaba casado con otra mujer en cuya compañía vivía, pero que no sabía si era cierto o no, pese a que había tratado de averiguarlo y que para ello estuvo, hacía dos años, con el Provisor de Cuenca y que oficiase, como lo hizo, al Provisor de Valladolid para que éste, indagase y averiguase la certeza de este hecho. Y que deseosa de saber las resultas de su petición, le preguntó al Provisor si había habido contestación, a lo que éste, le respondió que todavía no había noticias de lo solicitado.

Añadió a continuación en su declaración, que la anterior víspera de Año Nuevo, estuvo su marido en Cuenca, en casa de ella, durante un día y medio, en cuyo espacio y a fuerza de los muchos cargos y reflexiones que la declarante le hizo en cuanto a no hacer vida con ella y en averiguación de si era o no cierto que estaba casado por Valladolid con otra, solo le contestó que era cierto que tenía un hijo pero que no estaba casado, aunque sí amancebado.

La segunda vez que presta declaración Juana Collado, se lleva a cabo en Cuenca el 23 de febrero de 1820 ante el padre don Juan Nor- 
berto Cantero, Comisario del Santo Oficio, estando presentes por honestas y religiosas personas, los padres Felipe de Castro y Miguel Ibáñez, presbíteros, obligándose ambos a guardar secreto.

Fue preguntada que si se acordaba haber depuesto ante algún juez contra alguna persona sobre cosas tocantes a la fe, a lo que respondió que efectivamente, lo había llevado a cabo ante el juez que en esos momentos le preguntaba contra su marido Manuel Riñón.

A continuación, fue informada de que era propósito del promotor Fiscal del Santo Oficio, el presentarla como testigo ad perpetuam rem memoriam ${ }^{24}$ en un asunto contra su marido y que estuviera pendiente de su llamada para la declaración correspondiente. Seguidamente se le hizo lectura de sus declaraciones por si tuviera necesidad de alguna enmienda o añadido y su posterior ratificación sobre le declarado, a lo que la declarante manifestó estar en todo de acuerdo respecto a lo que había manifestado contra su marido Manuel Riñón, a continuación lo ratificó, afirmando que todo lo hacía por descargo de su conciencia y no por odio o venganza.

Fue preguntada sobre el viaje realizado a Madrid con su marido y sobre si había oído a alguien que su marido estaba casado con otra mujer y respondió, que estando su marido empleado en Madrid, en el Resguardo en la Puerta de Recoletos, fue a buscarle; pero que como vio que no le hacía ni caso, se volvió a Cuenca y siguió afirmando que no había oído si estaba o no casado. En cuanto a la pregunta de que si sabía que su marido hubiera regresado a Valladolid y vivía en compañía de otra mujer o si conocía la parroquia a que pertenecían ambos, dijo saber que su marido había regresado a Valladolid por dos cartas que le había enviado con fechas de 20 y 24 de enero, aportando dichas cartas en ese acto, pero que no sabía en qué parroquia vivía, ni si tenía en su compañía a la otra mujer e hijos. Para acreditar que

${ }^{24}$ Instrucción 1816. Fórmula para ratificaciones de los testigos ad perpetuam rei memoriam. El Comisario buscará dos Presbíteros Seculares Regulares que no sean del Oficio, los cuales prestarán juramento de guardar secreto y con su asistencia se recibirá y formalizará la ratificación que deben firmar; lo que ejecutará en la forma siguiente: En la ciudad, villa o lugar de........... tantos días de tal mes y año. siendo tal hora de la mañana o tarde, sobre poco más o menos, ante D. N., Presbítero, Comisario del Santo Oficio de la Inquisición de.......... de D. N. que hace de Notario en estas diligencias. Compareció siendo llamado y juró por Dios nuestro Señor de decir verdad y guardar secreto.

La ratificación ad perpetuam rei memoriam deberá ejecutarse cuatro días después de hecha la declaración; pero si el denunciante o cualquier testigo estuviese enfermo con mucho peligro o de próxima partida que se entienda no podrá ser habido pasados dichos cuatro días, se ejecutará antes la ratificación ante personas religiosas, y en la forma que queda expresada. 
había hecho diligencias en aras de averiguar este hecho, exhibió un testimonio dado por Manuel González de Santa Cruz el 11 de julio de $1816^{25}$.

\section{PRUEBA DOCUMENTAL}

Como prueba documental, se presentan sendas cartas que había enviado Tomás Riñón a su mujer en Cuenca, Juana Collado y las diligencias del Notario de Cuenca Manuel de Santa Cruz solicitando se certificase si en Valladolid constaba otro matrimonio de Tomás Riñón y que estaba dirigido al Vicario de Valladolid y que dicen así:

\section{VIII.A. Cartas}

La primera carta está redactada por Juan Riñón desde Valladolid a principios de enero de 1820 y va dirigida la correspondencia a nombre de Juana Collado y Riñón que por entonces se encontraba en Cuenca. Esta carta está dada como respuesta a la enviada por esta última y en ella le manifiesta su satisfacción de que tanto Juana, como su hijo Tomás y la madre de Juan Riñón se encontrasen bien de salud a la vez que le manifiesta encontrarse también él en perfectas condiciones.

En la carta enviada por Juana, ésta, le declara su deseo de ir a Madrid con su hijo Tomás para estar los tres juntos, a lo que Juan Riñón le manifiesta su alegría y se ofrece a estar junto a los dos y se ofrece ayudarle en todo lo que fuese menester. Asimismo, le advierte, que la decisión de ir a Madrid, debería consultarla con su hijo Tomás y que por su parte le concede licencia para que Juana y Tomás se trasladen a Madrid; pero le advierte que debe de ser avisado antes, para hacer un memorial dirigido al rey que debía entregar al coronel y que éste, se lo pasara al capitán general. Continúa diciéndole que ya había tomado cartas en el asunto habiendo hecho un memorial entregado al capitán general y que debía entregar antes al coronel para que se le abonasen los gastos correspondientes al aumento de cargas por parte de Juan, al residir Juana y su hijo Tomás en Madrid con él, pero que hasta la fecha no le habían sido abonados aunque el capitán general le había prometido ser de inmediato y estaba sospecho de que fuera ser así.

${ }^{25}$ ADC, leg. 747C, n. ${ }^{\circ}$ 1806, ff. 6-12. 
También le recuerda la obligación que tiene Juana de presentarse ante el comandante de armas y que éste, le preguntaría el por qué no la había llevado a Madrid a vivir con él y que ya el capitán general le había recriminado en más de una ocasión el haberlo hecho así; a lo que este argumentaba que lo habían acordado de común acuerdo el hacerlo de esa manera, ya que en caso contrario, le obligarían a ir a buscarla junto a su hijo para poder vivir juntos.

Al mismo tiempo, le insinúa que si la intención de ir Juana a Madrid, es la de poder luego regresar todos juntos a vivir a Cuenca debido a las malas condiciones económicas y de destino que tenía Juan en Valladolid y así poder lograr su jubilación en Madrid. Continúa manifestándole su preocupación por su hijo Tomás y su deseo de tenerlo a su lado y estar los tres juntos y destinarle algunos ahorros para su futuro y que no se olvidaba de él y del encargo de Tomás y que lo tenía muy presente para su compra; pero que todo lo dejaba a resultas de la determinación que tomara Juana.

Tras recordarle su feliz estancia con ella en Cuenca; pero que su encuentro con Tomás, le produjo una mala sensación, pues lo notó muy extraño y se quedó asustado por ello. Termina la carta llamándola querida esposa y le reitera la intención de estar los tres juntos. Al mismo tiempo le envía para el traslado a la madre de él recuerdos y le manifiesta que siente mucho el saber que está sola pero que su intención es favorecerla, pues no olvida la obligación que tiene con ella como hijo y ser ese su deseo. Y se despide como su apasionado esposo. Al final de la carta hay una cierta amargura y frustración contra su hermano Eusebio, el cual se encontraba allí en Valladolid examinándose de maestro de primeras letras, pues al solicitarle ayuda, éste, le contestó que hasta el verano no podía hacerlo. Al final está su firma y rúbrica.

La segunda carta es de fecha 20 de enero de 1820 y también en Valladolid. Empieza la misma llamándola querida esposa y relatando las muchas penurias pasadas para llegar a esa ciudad, debido a las continuas nevadas y lluvias durante el viaje. Pero su desconsuelo, le decía, era el no tener noticias suyas y sobre todo el no haberle enviado el memorial para el capitán general. Le recuerda que si lo estimaba como su marido, iría a ver al comandante y le preguntaría por su asunto. También, los lazos que le unían a esa tierra y a su tío y la tía Paulina y sobre todo la continua recriminación del capitán general por no haberlos llevado a ella y a su hijo con él. Haciendo eso me demostrarás, le dice, que lo amaba y que si no lo hacía así, iría a Cuenca a por ella y la llevaría consigo. 
Sigue recordándole a su hijo Tomás que no se había olvidado de su encargo y que cuando recibiera su sueldo, le compraría un pañuelo y le ordena que le envíe su ropa a Madrid por el ordinario y que a su vez éste, la entregue al amo del mesón y éste, a uno de los ordinarios de Valladolid y lo entregaran a Manuel Collán en la misma ciudad. Termina la carta con la frase querida esposa y despidiéndose como su afectísimo esposo, no sin antes enviándole recuerdos a la madre de él y a un tal Francisco de Belmonte (Cuenca). Está recogida su firma y rúbrica.

\section{VIII.B. Requisitoria}

A continuación constan unas diligencias del Notario de Cuenca, Manuel de Santa Cruz, solicitando se certifique si en Valladolid consta otro matrimonio de Tomás Riñón, dirigido al Vicario de Valladolid y que son del tenor literal siguiente:

Don Manuel González de Santa $\mathrm{Cruz}^{26}$, Notario mayor, uno de los cuatro perpetuos de la audiencia episcopal de esta ciudad de Cuenca y su obispado. Certifico y doy fe: que en las diligencias practicadas a instancia de Juana Collado, mujer legítima de Manuel Riñón, natural de Aguilar de Campos, en razón de acreditar si ha contraído otro matrimonio el susodicho, y en las que se expidió requisitoria al señor Provisor y Vicario General de la ciudad de Valladolid en donde se dice residía, a fin de recibirle su declaración jurada sobre ello, con qué persona, en donde y en qué tiempo. Y para la compulsa de la partida de matrimonio, caso que lo hubiera contraído y en las cuales se halla presentada la del tenor siguiente: Partida. Yo don Juan Bautista Saiz, presbítero teniente de cura de la parroquia de San Gil de esta ciudad de Cuenca, certifico que en el libro de matrimonios que dice principio en 7 de noviembre del año pasado de 1791 y al presente sigue al folio 18 vuelto se halla la partida siguiente: en la Iglesia parroquial de San Gil de esta ciudad de Cuenca, a 4 de agosto de 1810; habiendo precedido una de las tres moniciones que manda el Santo concilio de Trento por haber dispensado las otras diligencias el señor provisor de este obispado por decreto de 26 de julio próximo la que se hizo al tiempo del ofertorio de la misa conventual celebrada en esta parroquia de San Gil el día 29 de dicho mes de julio, en que ocurrió la Dominica séptima post Pentecostés, y no habiendo resultado impedimento y en

${ }^{26}$ En la parte superior de la requisitoria está la leyenda siguiente: Papel de pago al Estado. Sello de Fernando VII. Para sobres de solemnidad, cuatro reales, sello cuarto, año de mil ochocientos diez y seis. 
virtud de despacho del expresado señor provisor con fecha de 31 del mismo mes de julio, yo don Juan Bautista Saiz, presbítero con licencia y expresa facultad de don Gabriel José Gil, cura propio de esta dicha parroquia, desposé por palabras de presente que hacen verdadero matrimonio, velé y di las bendiciones nupciales con misa a Manuel Riñón, natural de Aguilar de Campos, hijo de José y de Manuela del Mozo y Juana Collado, natural de esta ciudad, hija de Pedro y de Bárbara Gómez, ambos de estado soltero y sin intereses de esta parroquia, quienes por mí preguntados, según prescribe el ritual Romano, dieron y prestaron libremente por palabras de presente, sus mutuos y recíprocos consentimientos, siendo testigos don Joaquín López, tonsurado; Deogracias López y Pedro de Olarieta, vecinos de esta ciudad. Los contrayentes estaban habilitados en conformidad a reales órdenes, fueron examinados en doctrina cristiana y recibieron los santos sacramentos de penitencia y comunión, y para que conste lo firmo, $u t$ supra, don Juan Bautista Saiz.

Es copia de su original que queda extendida en dicho libro corriente de que se volvió a colocar en el archivo parroquial a que me remito. Y para que conste donde convenga doy la presente que firmo en Cuenca a 30 de diciembre de 1813, don Juan Bautista Saiz.

Concuerda con la certificación de la partida de matrimonio original que se halla colocada en las diligencias de que va hecha mención y éstas por ahora quedan en mi poder y oficio, de que doy fe y a que me remito. Y para que conste y obre los efectos conducentes de mandato del señor Provisor y de pedimento de la enunciada Juana Collado, vecina de esta ciudad de Cuenca, doy el presente que signo y firmo en ella a 11 de julio de 1816 .

Comprobación. Los escribanos del rey nuestro señor y del número de esta ciudad y su tierra que abajo signamos y firmamos, certificamos y damos fe, don Manuel González de Santa Cruz, por quien se haya dado el testimonio precedente Notario mayor del tribunal eclesiástico de esta ciudad y su obispado, uno de los cuatro de la audiencia episcopal y como tal, a todos los documentos y demás diligencias que libra se le ha dado y da certeza, fe y crédito judicial y extrajudicialmente y el signo y fuerza con que escribiente es, el cual acostumbra en todos sus escritos, y para que conste donde convenga, a instancia de la interesada damos la presente en Cuenca a 12 de julio de $1816^{27}$.

${ }^{27}$ ADC, leg. 747C, n. ${ }^{\circ} 1806$, ff. 16-17.

Existe el sello del Notario.

Manuel González de Santa Cruz (firma y rúbrica).

Existen cuatro sellos. 


\section{CUMPLIMENTACIÓN Y CREDIBILIDAD DE LAS INVESTIGACIONES}

De acuerdo con lo solicitado por el Santo Oficio de Cuenca, respecto a que el Comisario devuelva cumplimentada las averiguaciones pertinentes y de su posible credibilidad y validez, el Comisario Juan Norberto Cantero, con fecha 24 de febrero de 1820, responde a los Inquisidores, que a su entender le parece que se puede dar crédito a los testigos que había examinado, pues le habían parecido fidedignos, justificando que no había podido interrogar a Juliana y ratificar a los demás, por la suma dificultad que había para hacerlo. Las razones que daba el Comisario, consistían, en que eran unas personas que salían muy poco y que la casa estaba siempre muy concurrida de gente, por cuya razón no podía hacerse sin que se llegase a levantar sospechas Termina su declaración en el sentido de que lo único que puede decir e informar, es que los testigos no son gente formal ya que son solo de referencia, todo ello en base a las declaraciones prestadas por los mismos.

A tenor de lo que disponía la Instrucción de 1816, se requería que la información se enviase cerrada y sellada, informando el Comisario de lo que se le ofreciese, y del concepto que hubiere formado de los que habían revelado en cuanto a la verdad de sus declaraciones. Una vez examinados y ratificados todos, y una vez cerrada y sellada la información, el Comisario, la debería enviar original al Tribunal, siempre que fuera con persona de confianza. Si no fuese así, y utilizase el correo, debería avisar por si se le ofreciese alguna cosa de consideración que debiera advertir acerca de la calidad del denunciado, además de la fe que se pudiese dar a los testigos. El sobre escrito tenía que dirigirlo al Santo Oficio que correspondiera. En parecidos términos se recoge esta exigencia en la Instrucción de 1815 en su número 15. Se exige igualmente, que la información se envíe cerrada y sellada informando el Comisario de lo que le pareciese oportuno. Una vez recibida la denuncia tanto si resultaban contestes, como si no, una vez examinándolos todos y los que ellos dijeren también en sus contestaciones, cerrada y sellada la información la debía enviar original al Tribunal con persona de confianza, con su consideración acerca de la calidad del denunciado y de la credibilidad que se pudiera dar a los testigos. De nuevo se le recuerda al Comisario, que tenía la obligación de devolver las cartas que recibiese del Tribunal, origi-

Juan Manuel Navarro (firma y rúbrica).

José Félix Pastor (firma y rúbrica).

En testimonio de verdad. Dámaso Julián Grande (firma y rúbrica). 
nales y su respuesta, prohibiéndole por tanto al Comisario que se quedase con papel alguno, ordenándole que solo habría de evacuar la comisión.

Por tanto, el Comisario debía enviar un informe sobre la fe y el crédito que merecieran los testigos, y al mismo tiempo, sobre la vida y opinión pública del delatado. El Comisario tenía que hacer una exposición al margen de cada declaración, sobre el juicio acerca de la fe y crédito que merecía el testigo que acaba de examinar o del delator que voluntariamente se le hubiese presentado. Y de forma separada, tenía que informar con más extensión de la vida, costumbres y opinión pública de la persona delatada, procurando tomar las noticias más exactas y seguras de sujetos timoratos e imparciales, sin perder de vista nunca, la prudencia y la necesaria cautela, a fin de que no se percibiera el motivo de las investigaciones llevadas a cabo.

\section{RECEPCIÓN Y TRASLADO AL PROMOTOR FISCAL}

Después de verificados los autos de devolución y credibilidad de las investigaciones y una vez recibidas en febrero de $1820^{28}$, éstas, son remitidas al Inquisidor Fiscal por orden de los Inquisidores Miguel de Villar y Solera y Blas Manuel Sánchez Vallés.

\section{PETICIÓN DEL FISCAL}

Con fecha de 2 de marzo de $1820^{29}$, el Inquisidor Fiscal ${ }^{30}$ del Santo Oficio, el doctor Escamilla, tras la lectura y vista de las diligencias practicadas en virtud de la delación dada por Santiago Antelo Coronel, alguacil mayor del Santo Oficio y que llevan fecha de 14 de enero de 1820, dirigida contra Manuel Riñón del Mozo, natural de Aguilar de Campos y vecino de Valladolid, por sospechas de doble matrimonio; solicita en la Inquisición de Cuenca el 3 de marzo, como primera medida, la compulsa de la partida de matrimonio contraído entre Juana Collado, natural de Cuenca y el denunciado Tomás Riñón, que proviene del matrimonio celebrado en la Iglesia parroquial de San Gil y que igualmente, fuera examinado Juan Bautista Saiz, presbítero y teniente de cura de dicha parroquia, por ser él, el que asistió al matri-

\footnotetext{
${ }^{28}$ ADC, leg. 747C, n. ${ }^{\circ} 1806$, f. $18 \mathrm{v}$.

29 Íbid., f. 19.

30 Íbidem.
} 
monio. Al mismo tiempo, solicita que fueran examinados los testigos que presenciaron el citado matrimonio y que eran: Joaquín López, tonsurado, natural de Cuenca; Ignacio López y por último Pedro de Olarieta, vecinos de la misma. Termina su petición suplicando se sirva librar la correspondiente comisión de secreto y todo ello con arreglo a derecho.

\section{SEGUNDA COMISIÓN DE INVESTIGACIÓN MATRIMONIAL}

De nuevo, los Inquisidores conquenses ${ }^{31}$, ante la necesidad de compulsar la partida de matrimonio que celebró en la parroquial de San Gil de Cuenca, el 4 de agosto de 1810, el acusado Manuel Riñón, natural de Aguilar de Campos con Juana Collado, de Cuenca; comisionan al Comisario Cantero con fecha de 6 de marzo de $1820^{32}$, para que acompañado del Notario en las anteriores diligencias, y bajo juramento y promesa de guardar secreto, procedieran en pliego separado a recibir declaración al teniente de cura $^{33}$ de dicha parroquial Juan Bautista Saiz, acerca de si asistió a la celebración de dicho matrimonio, el día, mes y año en que ocurrió y dijera quienes fueron testigos del mismo. También en pliego separado, debía tomar declaración a los testigos: Joaquín López, clérigo tonsurado y Deogracias López que constaban como testigos de haber presenciado el acto, todo ello según lo prevenía el número 11 de la Instrucción de Comisarios. Una vez concluidas las mismas, debería dejar transcurrir 2 o 3 días para ser posteriormente ratificadas de forma ad perpetuam con arreglo a los números 18 y 19 de dicha Instrucción.

\footnotetext{
${ }^{31}$ Íbid., ff. 20r-20v.

32 Dada por el Licenciado don Miguel de Villar y Don Ignacio Rodríguez de Fonseca, Secretario.

${ }^{33}$ Instrucción 1816. In duplici matrimonio se examine el párroco y testigos instrumentales, y se saque fe del libro. Si la denunciación fuere de duplici matrimonio examinará entre los demás testigos, al Rector o Clérigo que los desposó por palabras de presente, y dijo la Misa nupcial y sacará una copia auténtica del asiento del matrimonio o matrimonios del libro de la Iglesia, compulsando; igualmente las partidas de bautismo de los hijos si los tuvieren y examinará a los testigos instrumentales y en su defecto algunas personas fidedignas que puedan tener noticia del asunto y si alguno fuere ya difunto ha de dar fe el Notario.

Instrucción 1815. N. 11. En causas de doble matrimonio se examine el Párroco y se saque fe del libro matrimonial. Si la denunciación fuere de duplici matrimonio examinará entre los demás testigos al Cura o Clérigo que los desposó por palabras de presente, y dijo la Misa nupcial y a los testigos que se hallaron presentes al desposorio pudiendo ser habidos y dará fe el Notario de los que no fueren hallados para dicho examen y sacará una copia auténtica del asiento del matrimonio o matrimonios del libro de la Iglesia.
} 


\section{INVESTIGACIÓN TESTIFICAL}

\section{XIII.A. Testigo Gabriel José Gil}

El día 7 de marzo de $1820^{34}$, los comisionados, se presentan a tomar declaración a Gabriel José Gil, cura propio de la parroquia de San Gil de Cuenca y le hicieron saber, que necesitaban compulsar una partida de matrimonio celebrado en su parroquia en el año de 1810 . Tras la puesta a disposición a los comisionados del libro de matrimonios correspondiente al año solicitado, libro que comenzaba el día 7 de noviembre de 1791, en el folio 18 vuelto, hallaron una partida de donde hicieron una transcripción literal del matrimonio solicitado ${ }^{35}$.

\section{XIII.B. Testigo Joaquín Julián López}

El 10 de marzo de 1820, los comisionados, se presentan a tomar declaración a Joaquín Julián López, tonsurado, residente en Cuenca y de edad de 45 años.

Cuando se le pregunta sobre la causa por la que es llamado, responde que no sabe nada. Respecto a la consulta sobre si se acordaba

${ }^{34}$ ADC, leg. 747C, n. ${ }^{\circ} 1806$, ff. 21r-21v.

${ }^{35}$ Que a la letra decía lo siguiente:

En la Iglesia parroquial de San Gil de esta ciudad de Cuenca, a 4 de agosto de 1810, habiendo precedido una de las tres moniciones que mandaba el Santo concilio de Trento por haber dispensado las otras dos el señor Provisor de este obispado por decreto de 26 de junio próximo, la cual se hizo al tiempo del ofertorio de la misa conventual celebrada en esta parroquia de San Gil el día 29 de dicho mes de julio en que ocurrió la dominica séptima post pentecostés, no habiendo resultado impedimento alguno y en virtud del despacho del expresado señor Provisor con fecha de 31 del mismo mes de julio. Yo don Juan Bautista Saiz, cura propio de esta dicha parroquia, desposé por palabras de presente que hacen verdadero matrimonio, velé y di las bendiciones nupciales con misa a Manuel Riñón, natural de Aguilar de Campos, hijo de José y de Manuela del Mozo y a Juana Collado, natural de esta ciudad, hija de Pedro y de Bárbara Gómez, ambos de Estado solteros y feligreses de esta parroquia, quienes por mí preguntados según prescribe el ritual romano dieron y prestaron libremente por palabras de presente sus mutuos y recíprocos consentimientos, siendo testigos don Joaquín López, tonsurado, Deogracias López y Pedro de Olarieta, vecinos de esta ciudad, los contrayentes estaban habilitados en conformidad a reales órdenes, fueron examinados en doctrina cristiana y recibieron los santos sacramentos de penitencia y comunión. Y para que conste lo firmo ut supra: don Juan Bautista Saiz.

Es copia fiel y legalmente sacada y conviene a la letra con su original que obra en el libro y folios ya citados el cual devolví a dicho señor exhibiente y para que así conste y obre los efectos que haya lugar. Y la presente firmada de dicho señor Comisario en la denominada ciudad de Cuenca día, mes y año expresados.

Juan Norberto Cantero (firma y rúbrica). Don Julián Ruíz, Notario (firma y rúbrica). 
haber sido testigo del matrimonio de Manuel Riñón, natural de Aguilar de Campos y Juana Collado de Cuenca, celebrado en la parroquia de San Gil de dicha ciudad, dijo que se acordaba perfectamente haber sido testigo de dicho matrimonio el cual se celebró con arreglo a lo que disponía el ritual católico. Sobre la pregunta respecto a que si se acordaba del día, mes y año en que ocurrió y quienes fueron testigos, dijo que no se acordaba del día, mes ni año en que ocurrió ni quiénes fueron los otros testigos ${ }^{36}$.

\section{CONCLUSIONES}

Las figuras claves en las diligencias para averiguación de los delitos de bigamia que intervienen en ellas, son sin duda alguna el Comisario y el Inquisidor Fiscal, siendo la actuación de las demás personas intervinientes en el proceso, más un actuación de mero trámite, que resolutiva. Las intervenciones de los dos primeros y sus resoluciones en los procesos en que intervienen, pueden determinar con sus opiniones una sentencia favorable o no para el denunciado.

Es de destacar igualmente y como era norma inexcusable en el Santo Oficio, el secreto con que se llevan a cabo todas las diligencias que practican los diferentes miembros de la Inquisición en sus intervenciones, hasta tal punto, que el propio acusado, jamás se enteró de la apertura del expediente incoado contra él, ni las diligencias usadas para su averiguación, pues el acusado de ningún modo estuvo presente y nunca intervino con sus declaraciones y manifestaciones en el proceso.

También hay que destacar en estas actuaciones o diligencias de la Inquisición de Cuenca, la decadencia o periodo de crisis por el que atravesó esta institución durante el siglo decimonónico, que no hay que olvidar que se venía arrastrando ya de siglos anteriores y que se detectan en los aspectos económicos y administrativos del Santo Oficio, pero que sin embargo, no por eso, dejaban todavía de inspirar terror en la población española y no digamos en los acusados, que a la menor sospecha, huían precipitadamente de sus lugares. Igualmente se pueden detectar, tras el estudio de los expedientes en el Archivo Diocesano conquense, la cantidad de denuncias sobre el delito de bigamia, en las que apreciamos, una reducción indicadora, al igual que en las demás denuncias de otros delitos. Y por último y quizás lo más significativo, es la suavidad de las sentencias que dicta el tribunal de

${ }^{36}$ ADC, leg. 747C, n. ${ }^{\circ} 1806$, f. 22. 
EL COMISARIO EN LAS PRIMERAS DILIGENCIAS DE INVESTIGACIÓN...

Cuenca, tras las diligencias practicadas para averiguación de este delito, que significa en definitiva el abandono y decadencia del sistema inquisitorial.

\section{BIBLIOGRAFÍA}

AGUILAR, M., Historia de la Inquisición, Las Palmas, 1874.

ALCALÁ, A., Inquisición española y mentalidad inquisitorial, Barcelona, 1984.

ALCÁZAR, C., «Aportación a la polémica sobre la Inquisición española», en Revista de estudios políticos, 1945, pp. 140-157.

ALVARADO PLANAS, J., «Juristas turbadores: de la censura inquisitorial a la literatura jurídica y política (siglos XVI-XVII)» en Javier Alvarado (ed.) Historia de la literatura jurídica en la España del antiguo régimen, vol. I, Madrid, 2000.

ALVAREZ DE MORALES, A., «La crítica al Tribunal de la Inquisición durante la segunda mitad del siglo XVIII», Estudis, 6, 1977.

BARRIOS, F., El Consejo de Estado en la Monarquía española, 15211812, Madrid, 1984.

- Los reales Consejos. El gobierno central de la Monarquía en los escritores sobre Madrid del siglo XVII, Madrid, 1988.

BENNASSAR, B., Inquisición española. Poder político y control social, Barcelona, 1981.

- Los españoles, actitudes y mentalidades, Madrid, 1984.

- Los cristianos de Alá. La fascinante aventura de los renegados, Madrid, 1989.

BLAZQUEZ MIGUEL, J., La Inquisición en Castilla La Mancha, Madrid, 1986.

- La Inquisición en Albacete, Albacete, 1985.

CARO BAROJA, J., El señor Inquisidor y otras vidas por oficio, Madrid, 1968.

- Los moriscos del Reino de Granada, Madrid, 1957.

- Vidas mágicas e Inquisición, Madrid, 1967.

(C) UNED. Revista de Derecho UNED, núm. 16, 2015 


\section{Eulogio Fernández Carrasco}

CIRAC ESTOPIÑAN, S., Los procesos de hechicerías en la Inquisición de Castilla la Nueva. Tribunal de Toledo y Cuenca. Aportación a la historia de la Inquisición española, Madrid, 1942.

- Registro de los documentos del Santo Oficio de Cuenca y Sigüenza, Barcelona, 1965.

CONTRERAS, J., «Las causas de fe en la Inquisición española (15401700). Análisis de una estadística», en Simposio interdisciplinario de la Inquisición Medieval y Moderna, Copenhague, 1978.

CONTRERAS, J., y DEDIEU, J. P., «Geografía de la Inquisición española. La formación de los distritos (1480-1820)», Hispania, 140, 1980.

DOMÍNGUEZ NAFRÍA, J. C., La Inquisición de Murcia en el siglo XVII: el licenciado Cascales, Murcia, 1995.

ESCUDERO, J. A., «La Inquisición española», en Historia 16, extra 1, diciembre, Madrid, 1976.

- «La reconstrucción de la Administración Central en el siglo XVIII», en Historia de España, dirigida por Menéndez Pidal, tomo XXIX, Madrid, 1985.

- Perfiles jurídicos de la Inquisición española, Madrid, 1989.

FERNANDEZ CARRASCO, E., Historia del Derecho Local en Cuenca, Madrid, 2005.

- La Inquisición. Procesos y Autos de Fe en el antiguo Régimen. Madrid. 2007.

- «Autos Particulares de Fe celebrados en la Inquisición de Cuenca durante el reinado de Felipe V (años 1721-1725)», Intolerancia e Inquisición, (Edic.) José Antonio Escudero, Madrid, 2005, vol. III, pp. 519-558.

- «Autos de Fe en Cuenca durante el reinado de Felipe IV (años: 1654 y 1656)», en Revista de la Inquisición, 11, Madrid, 2005. pp. 279-317.

- «Expediente de purificación a la Inquisición de Cuenca. El proceso del Inquisidor Blas Sánchez Valles», en Revista de la Inquisición, 18, Madrid, 2014. pp. 11-30.

- Las minorías religiosas bajo la monarquía española. La intolerancia en el tribunal de la Inquisición de Cuenca. Edic. Alvarado Planas Javier. Madrid. 2011. Pp. 277-299. 
El COMISARIO EN LAS PRIMERAS DILIGENCIAS DE INVESTIGACIÓN...

- «La Inquisición en Cuenca: El Auto de Fe de 12 de agosto de 1590», en Revista de Derecho UNED RDUNED, 4, Madrid, 2009, pp. 45-79.

- «La confiscación como límite jurisdiccional de la Inquisición a los señorios. El caso del Fisco de la Inquisición de Cuenca y el $V$ duque de Medinaceli», en Revista de Derecho UNED RDUNED, 13, Madrid, 2013, pp. 221-244.

- «El Santo Oficio en Cuenca. La relación del Auto General de Fe de 1583", en Revista de Derecho UNED RDUNED, 12, Madrid, 2013, pp. 159-187.

- "Masonería e Inquisición en Cuenca a finales del XVIII y comienzos del XIX. Los procesos de Ayguibelle y Merino», en Revista de Derecho UNED RDUNED, 15, Madrid, 2014, pp. 233-253.

GACTO, E., "Aproximación al Derecho penal de la Inquisición», en Perfiles jurídicos de la Inquisición española, Madrid, 1989.

GARCÍA ARENAL, M., Inquisición y moriscos. Los procesos del tribunal de Cuenca, Madrid, 1978.

JIMÉNEZ MONTESERIN, M., Introducción a la Inquisición española. Documentos básicos para el estudio del Santo Oficio, Madrid, 1980.

LOWER, T., La Inquisición, Barcelona, 1975.

KAMEN, H., Los caminos de la tolerancia, Madrid, 1967.

- La Inquisición española, Madrid, 1973.

LEA, H. CH., Historia de la Inquisición española, Madrid, 1983.

LORENZO CADARSO, P. L., "Oligarquías conversas de Cuenca y Guadalajara (siglos XV y XVI)», Hispania, 186, (1994).

LLORENTE, J. A., Historia crítica de la Inquisición en España, Madrid, 1822.

- Memoria histórica sobre cuál ha sido la opinión nacional de España acerca del Tribunal de la Inquisición, Madrid, 1812.

MARTÍNEZ MILLÁN, J., La Hacienda de la Inquisición (1470-1700), Madrid, 1984.

- «Crisis y decadencia de la Inquisición», en Cuaderno de Investigación histórica, 1-17, 1983.

— «La Inquisición española (1478-1700)», en Historia económica, Madrid, 1987. 


\section{Eulogio Fernández Carrasco}

MELGARES MARÍN, J., Procedimiento de la Inquisición, persecuciones religiosas, origen y carácter eclesiástico de la Inquisición, escándalos de los Inquisidores, frailes y Papas, terrible lucha de la Inquisición contra el pueblo español, engaños, tretas, misterios, injusticias. La Inquisición y las Cortes de Cádiz, procesos más notables, Madrid, 1886.

PÉREZ MARCOS, Regina M. ${ }^{a}$, "Derechos Humanos e Inquisición, ¿conceptos contrapuestos?», en Revista de la Inquisición, 9, (2000).

PÉREZ RAMÍREZ, D., Catálogo del Archivo de la Inquisición de Cuenca, Madrid, 1982.

PÉREZ VILLANUEVA, J. (Dir.): La Inquisición española nueva visión, nuevos horizontes (1 er Symposium internacional sobre la Inquisición española), Madrid, 1980.

- Historia de la Inquisición en España y América, Madrid, 1984.

TOMAS Y VALIENTE, F.: La tortura en España. Estudios históricos, Barcelona, 1973.

— «El proceso penal», en Historia 16, extra I, Madrid, 1976.

VALLE, J., Anales de la Inquisición, desde que fue instituido aquel tribunal hasta su total extinción en 1834, Madrid, 1841.

VARIOS AUTORES. «Intolerancia e Inquisición». Edición de José Antonio Escudero, Sociedad Estatal de conmemoraciones culturales, 2005. 
EL COMISARIO EN LAS PRIMERAS DILIGENCIAS DE INVESTIGACIÓN...

XVI. APÉNDICE I. CARTILLA DE COMISARIOS DE CUENCA

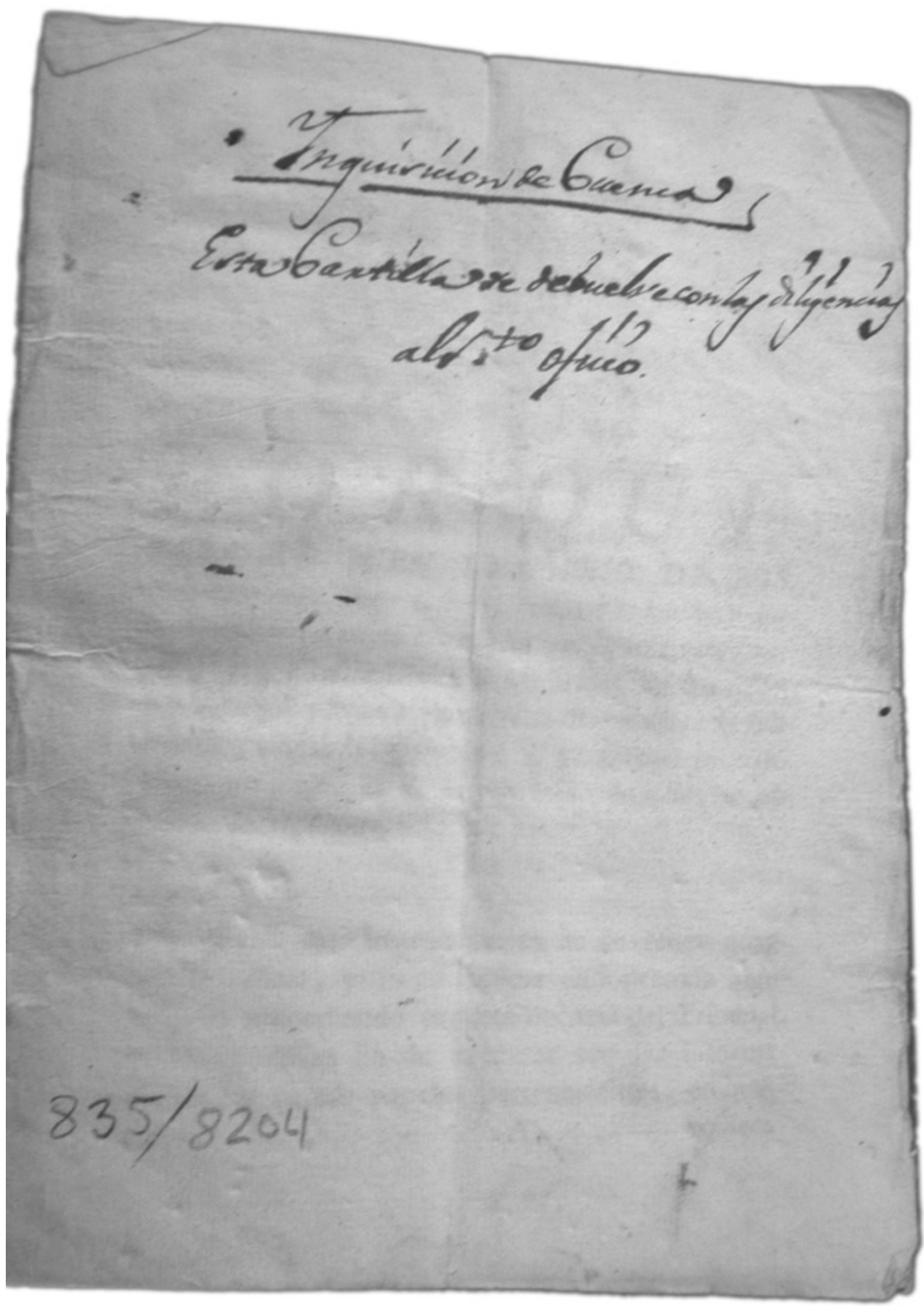




\section{Eulogio Fernández Carrasco}

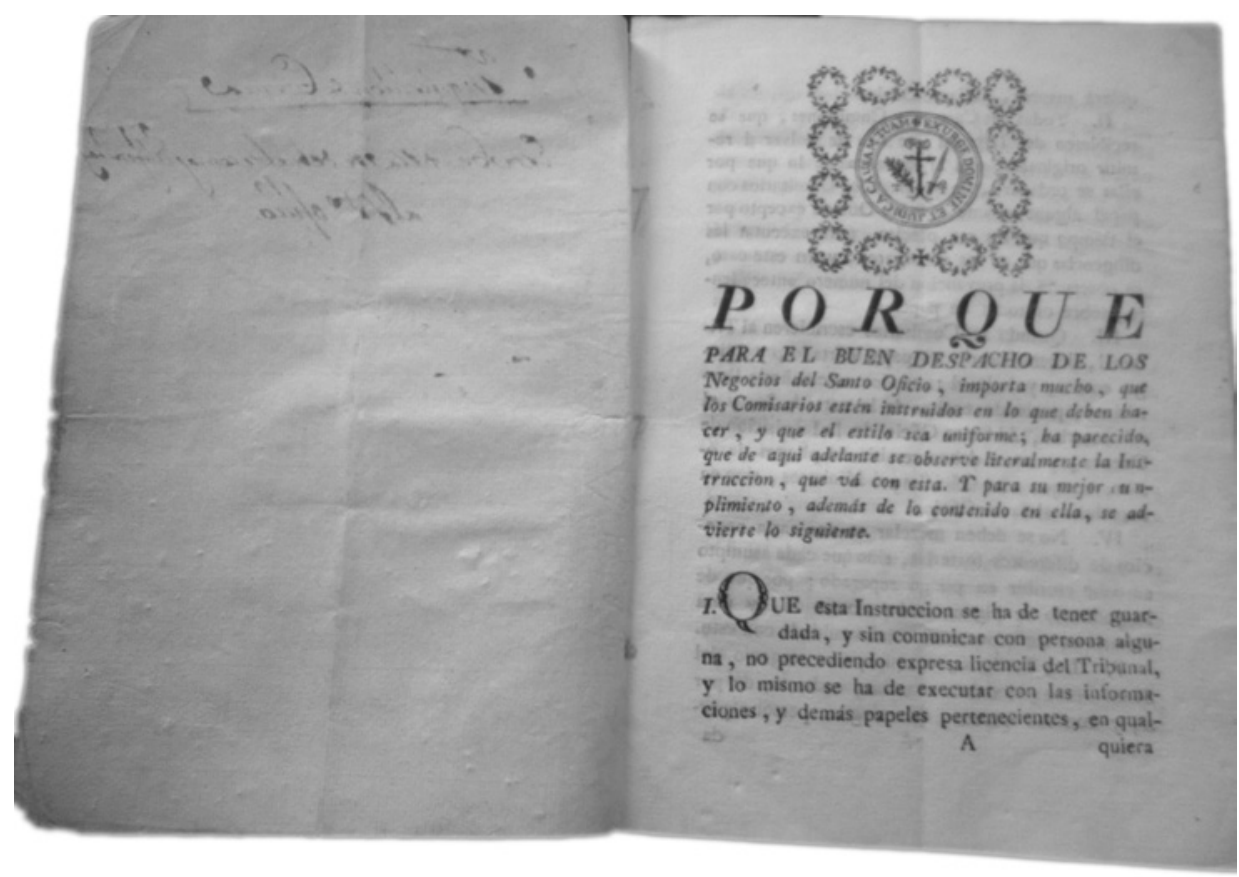

quiera manera, al Suato Oficio.

II. Todas las Cartas, $y$ Comisiones, que se recibierea del Tribual, se han de bolver á remitir originales, con la respuesta de lo que por ellas se ordenare, sin quedarse los Comisarios con papel e' e! tiempo que les sea preciso, para executar las diligencias que se les encargaren; $\boldsymbol{y}$ en este caso, se observará la prevencion del numero antecedente, sobre custodia de papeles.

III. Quando los Comisarios escribieren al Tri. bunal, deben hacerlo en papel cortado, y pliego entero, $y$ darle el tratamiento de Señoria Ilustrisima, poniendo encima de la carta I. S., y el sobreescrito, Al Santo Oficio de la Inquisicion de Cuenca, y no se deben remitir en pliegos de ótros, aunque sean Oficiáles, ó Ministros, sino en derechura al Saato Oficio.

IV. No se deben mezclar en una carta negocios de diferentes materias, sino que cada asumpto se debe escribir en pliego separado; por que de lo contrario se sigue mucha confusion, y para evitarla es necesario tenee mucho euidado con esto.

V. Los Testigos, ea qualquiera negocio del Santo Oticio, se d:bea examinar cada uno de por si, y con tal secreto, que niaguna persona pue- da oir, ni lentender fo rpue el testigo dixere y de. dlarare; $y$ ininguno de ellos debe saber, qué han declarado otros, ni se les debe air neticia da quienes han de declarar, aunque ellos los hayan eltado, por el peligro que hay, de que los prevengan, $y$ concuerden sus dichos, advirtiendoles to que han dicho, para que declaren segun ello. y estén concordes.

VI. En cada testigo se pondrá la cabeza como en el primero, cun lugir, dia, més, y ăbo, de la misma suerte, que sino se hubiera examinado otro itguno, poes de este modo se evitara que los testigos puedan conocer que se haa exa. minado otros,

VII. Los juramentos de los testigos no se han de poner cono diligeneias separadas (lo qual algunos que no saben el estilo del Santo Oficto han hecho) sino insertas en la cabeza de las declaraciones.

Y VIII. EI nombre del testigo se debe poner en principio de renglon, lo mismo se debe executar con las preguntas, y respuestas, y estas se ha de procurar que sean del iatento, $y$ no impertinen.

IX. Las preguntas se han de estender al pie de la letra, como se hicieren, y se hade teacr $\mathrm{A}_{2}$ muy 


\section{EL COMISARIO EN LAS PRIMERAS DILIGENCIAS DE INVESTIGACIÓN...}

vay particular cuidado ea que no sean sugestivas, pata lo que conducirá mucho limitatse at metodo de la Cartilla , ó Instruccion

$X$. Cada declaracion que se recibiere en inateria de Fé, se debe escribir en pliego separado, dexando ea blanco, $y$ sin borrar lo que sobrare de papel, por que esto sirve para poner las radexar algun hueco proporcionado el caso; $y$ no basta ocupar la ratificacion por que muchas veces se suelen ratificar los restigos ques de was vez, tieien ratificar los testigos mas de una vez, o tienen que añadir mucho, 6 se necesitan volver á examinar, y no pudiendose colocar las declaraciones de uno mismo consecutivas, resulta con. fusion en los procesos.

XI. El sér, y conservacion del Santo Oficio consiste principalmente en el Secreto que se debe guardar ea las cosas de él, conforme al juramento que hicieron los Comisarios, y demás Ministros al tiempo de ser admitidos á sus Oficios; y no solo le debea observar en las Causas de Fé, ó dependientes de ellas, ea qualquiera manera, sino tambien de todas las Cartas-Ordenes, $y$ avisos del Tribunal, $y$ de las Informaciones de limpieza que hubieren hecho, ó hicieren, $y$ de to-

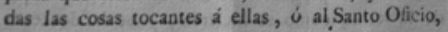

aunque sean publicas, pues hay precisa obligacion aunque sear pubere todos los casos, y matede guadar secreto es de ellas a las partes, ni á rias, sin dar moticia de ellas a lase parres, nier persona alguna, directe, ni lindicecté, á ao ser à Ministro del Santo Ohicio, $\mathbf{y}$, esto solanente en caso necesario, ó quando coaveaga darle aviso para mejor expedicioa, y execucion del negocio, ò si tubieren licencia expresa del Tribunal. XII. Por que muchas veces sucede que los Comisarios necesitea de personas que no sean Ministros del Tribual, para hacer algunas diligencias, se advierte, que en este caso, babiendo Eclesiastico idoneo deben valerse de $\mathrm{el}, \mathrm{y}$ antes del Sacerdote, que del que no lo sea, y debe tomarseles ante todas cosas, jurameato de que guardarán secreto, y, que no descubrirán cosa alguna directé, ní indireế, so pena de perjutos, de infidelidad, $y$ de cien ducados, $y$ otras penas arbitrarias al Tribunal; $y$ esta diligencia se pondrá la primera, y separada de las demás.

XIII. Si ea el distrito, ó comarca, ea que el Comisario residiere, no hubiere Notario de el Santo Oficio, ó habiendole, estubiere legitimamente ocupado, ó impedido, ó por alguaa otra causa no conviniere que se hagan alguaas diligeacias ante el, y se bubieren de hacer ante otro que no sea Notario, 6 Familiar, si siendo reque rido de parte del Santo Oficio, para que vaya dár fe, $y$ acompañe al Counisario, a los lugares que fuere necesario, aungue sean distanies de dore de viviere, reth avisara de ello el Comisario al Tribunal, haciendo uny puntual, $y$ verdadera relacion de las escusas que huibiere dado, ó diere, para que en sia vista, se provea de remedio.

XIV. En teniendo el Comisario noticia de muerte de algun Notario, ó Familiar, de- los que hubiere en su comarca, debe dar noticia de ello al Tribunals $y$ de la misma suerte quando falleciere el Comisario, el Notario, ó Familiar de su comarca que se hallase mas cercano, debe acudir á entregarse de las cartas, é instrueciones tocantes al Santo Oficio que hubieren quedado por muerte del Comisario, y habiendolos recibido. los entregará al Comisario mas cercano, para que cerrados, $y$ sellidos los remita al Tribunal, dexando solamente a los herederos el Tirulo de $\mathrm{Co}$ úisario, si quisieren quedarse con él.

XV. En quanto à las informsciones de limpieza, que hicieren los Comisarios, procurando arreglarse á la Instcuccion especial, que para ellas se les diere, evitaráa muchos errores; y por a- ora se les advierte, que lo que se dice artiba sobre recibir los testigos en pliegos separados, no tiene luzat en dichas informaciones de limpieza, tiene lugates bien se deben excribir todas las disino que ances bien se deben cheribir codas las diligencias consecutivas sin dexar blanco alguno auoquando son de diferentes lugares: advirtieado que deben venir numerados al margea los Testigos, y sus edades; y que no se deben poner dos preguntas debaxo de un contexto, como hacea alguaos. Avisarános el Comisario puntualnente de quanto combenga noticiar al Tribunal, procuraado observar todo este orden, y el de la lastruecioa adjuata.

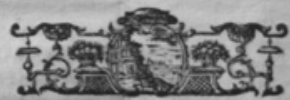




\section{Eulogio Fernández Carrasco}
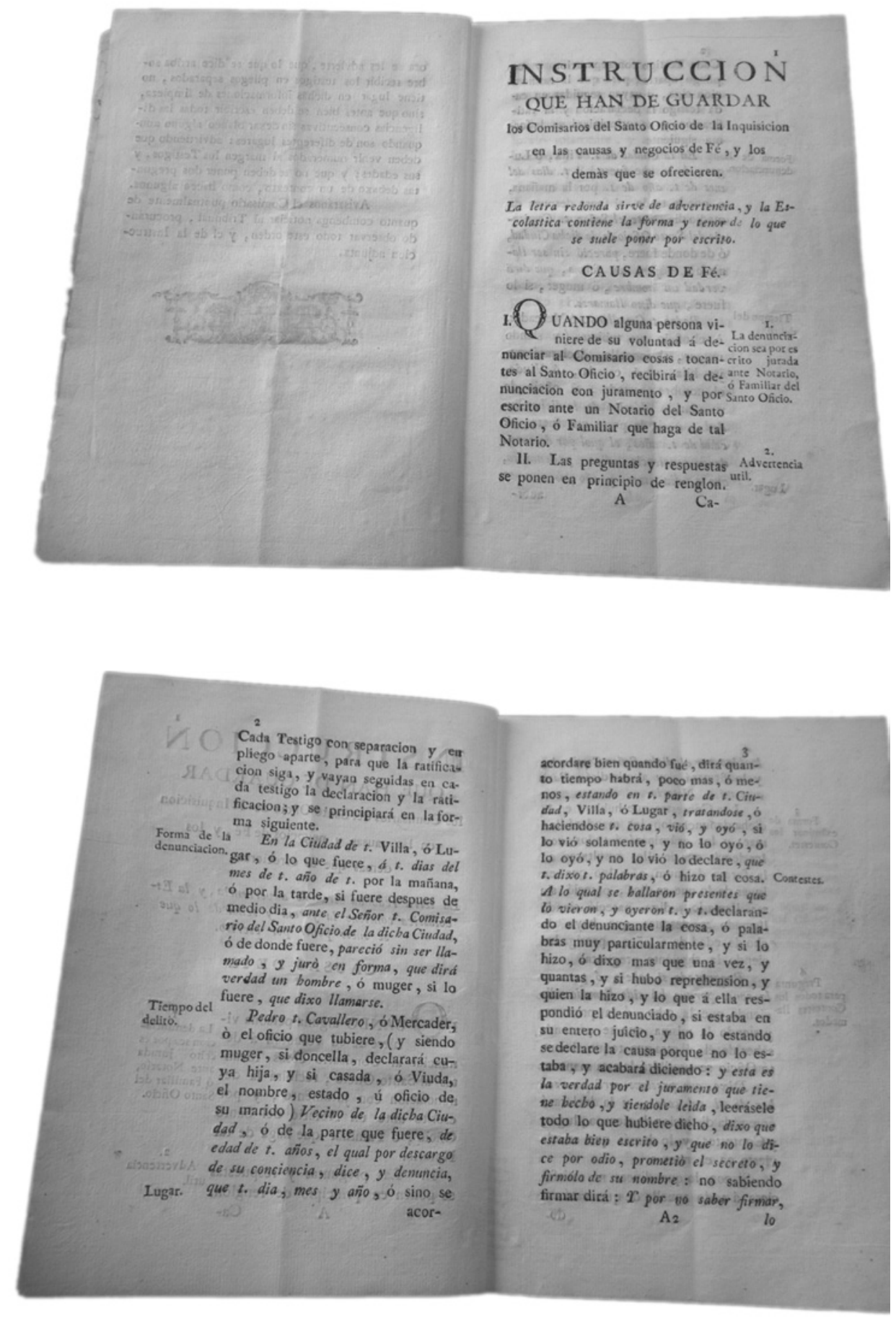


\section{EL COMISARIO EN LAS PRIMERAS DILIGENCIAS DE INVESTIGACIÓN...}
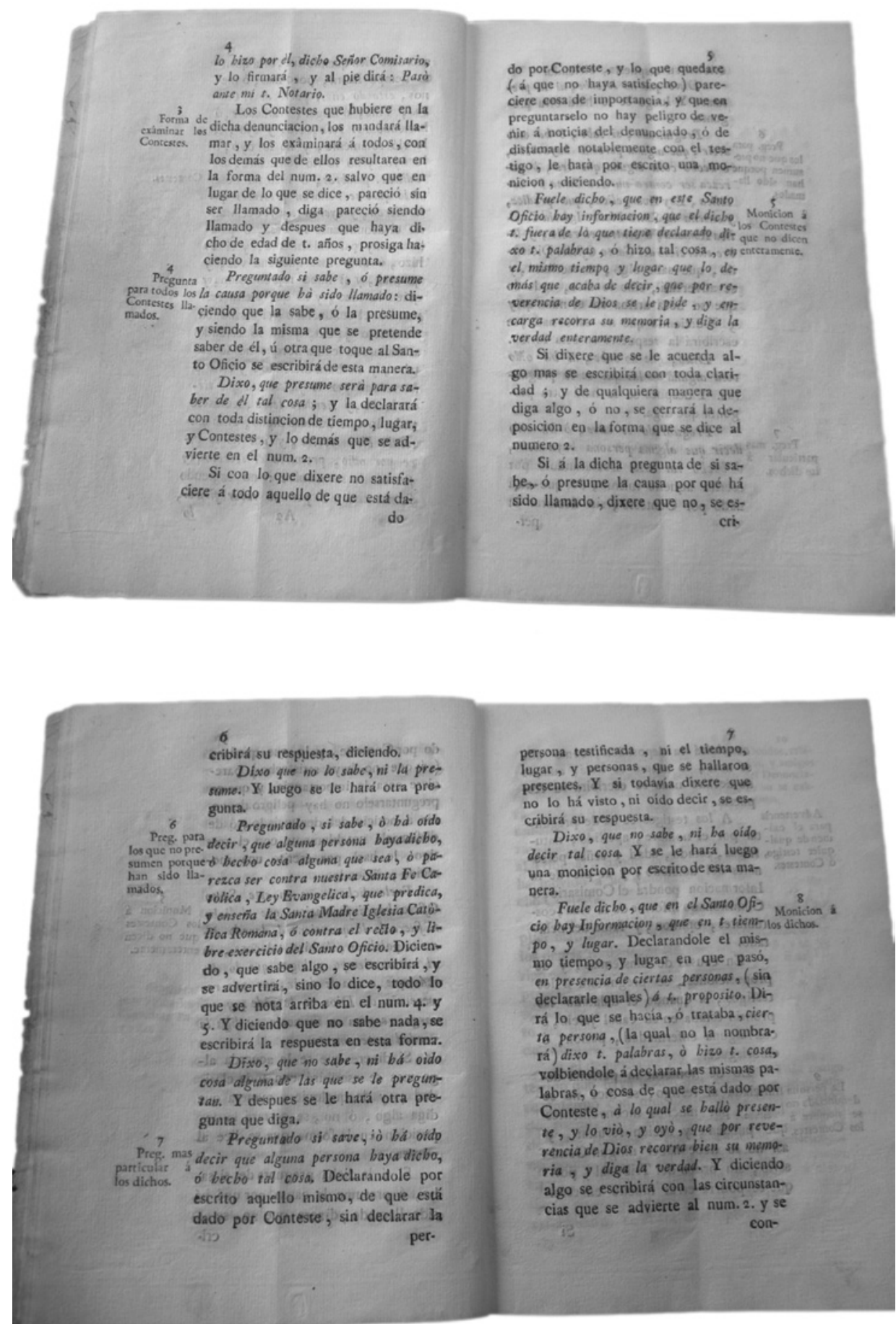


\section{Eulogio Fernández Carrasco}
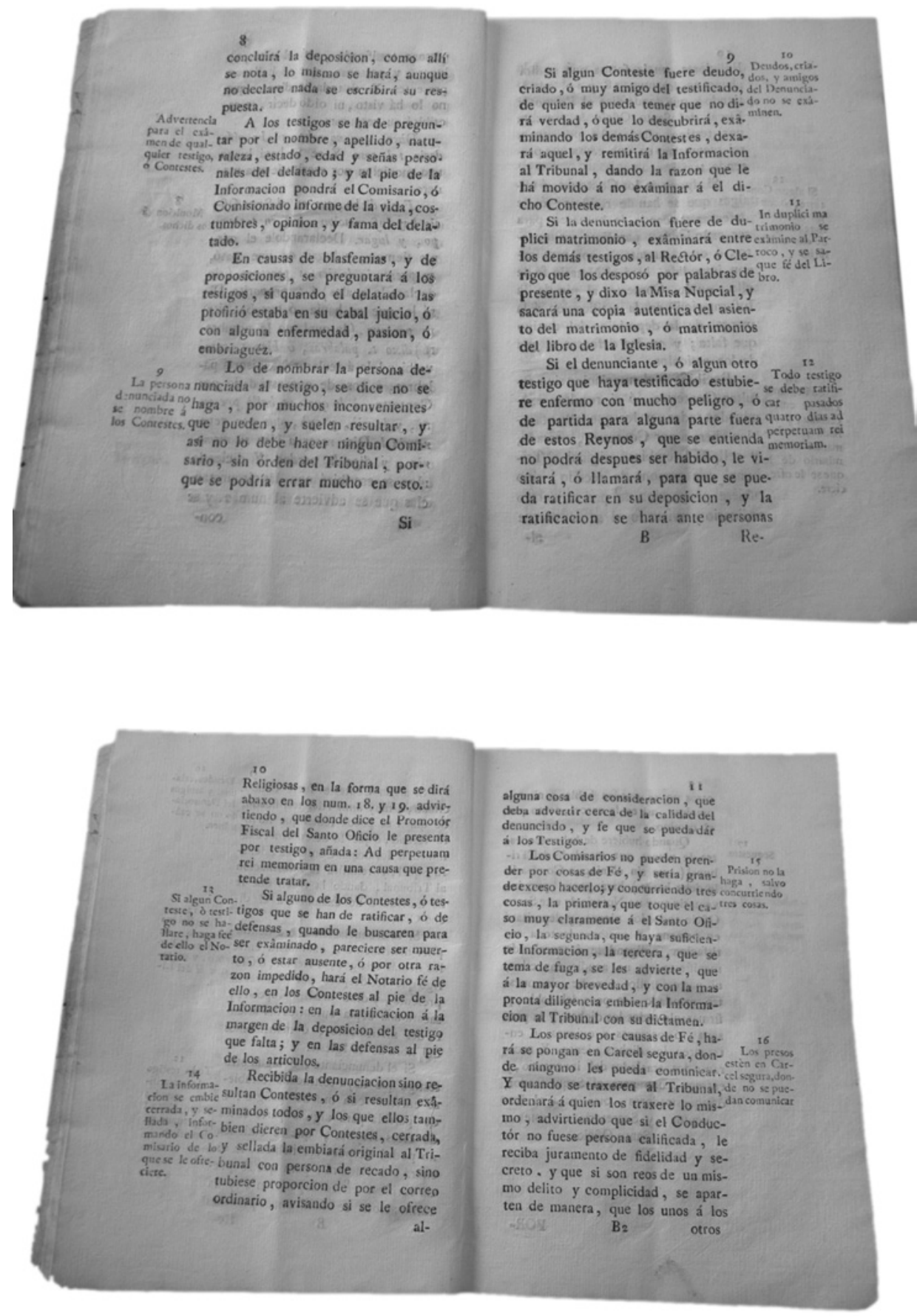


\section{EL COMISARIO EN LAS PRIMERAS DILIGENCIAS DE INVESTIGACIÓN...}
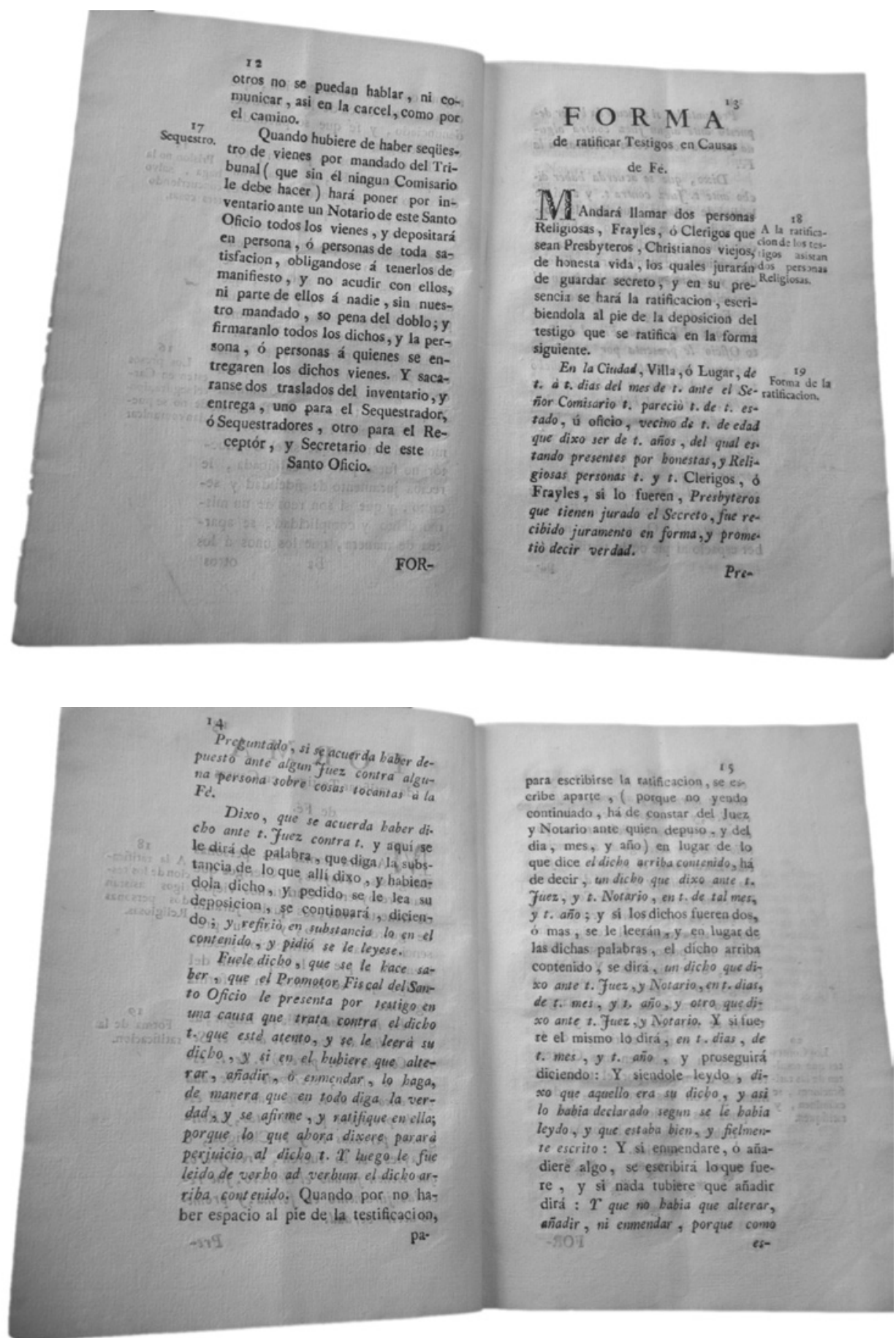


\section{Eulogio FERnández CARRASCO}
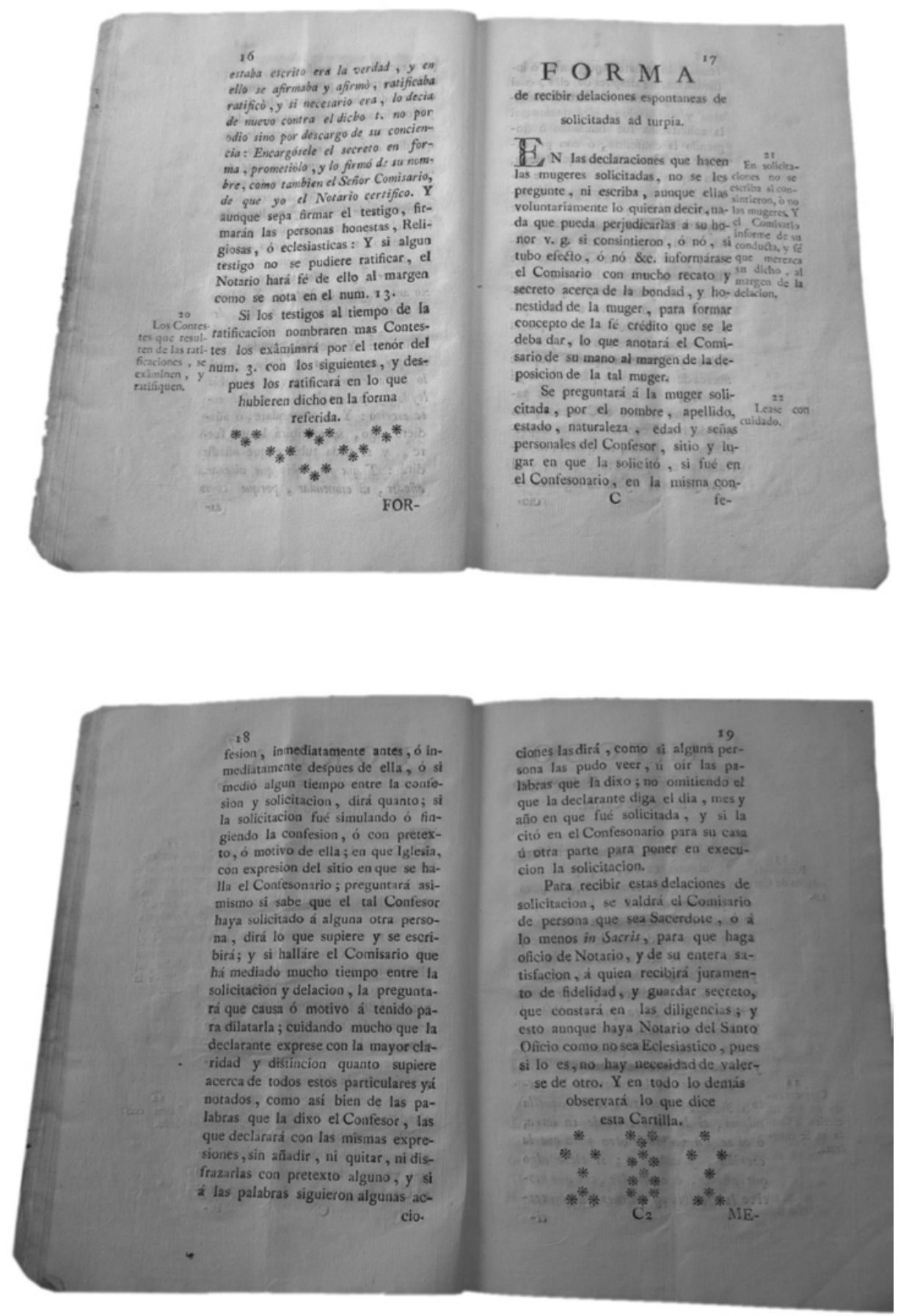


\section{EL COMISARIO EN LAS PRIMERAS DILIGENCIAS DE INVESTIGACIÓN...}
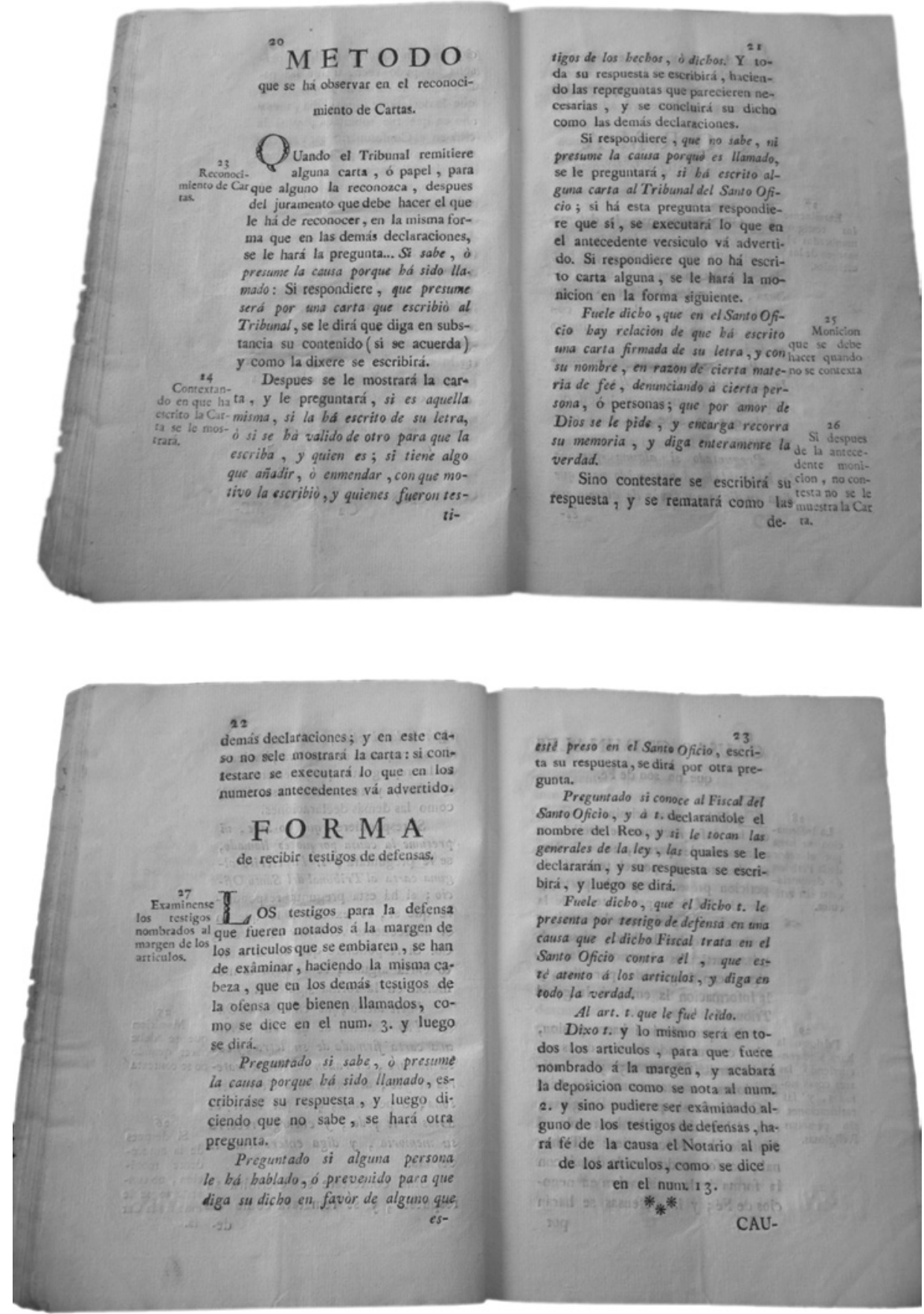


\section{Eulogio Fernández CaRrasco}
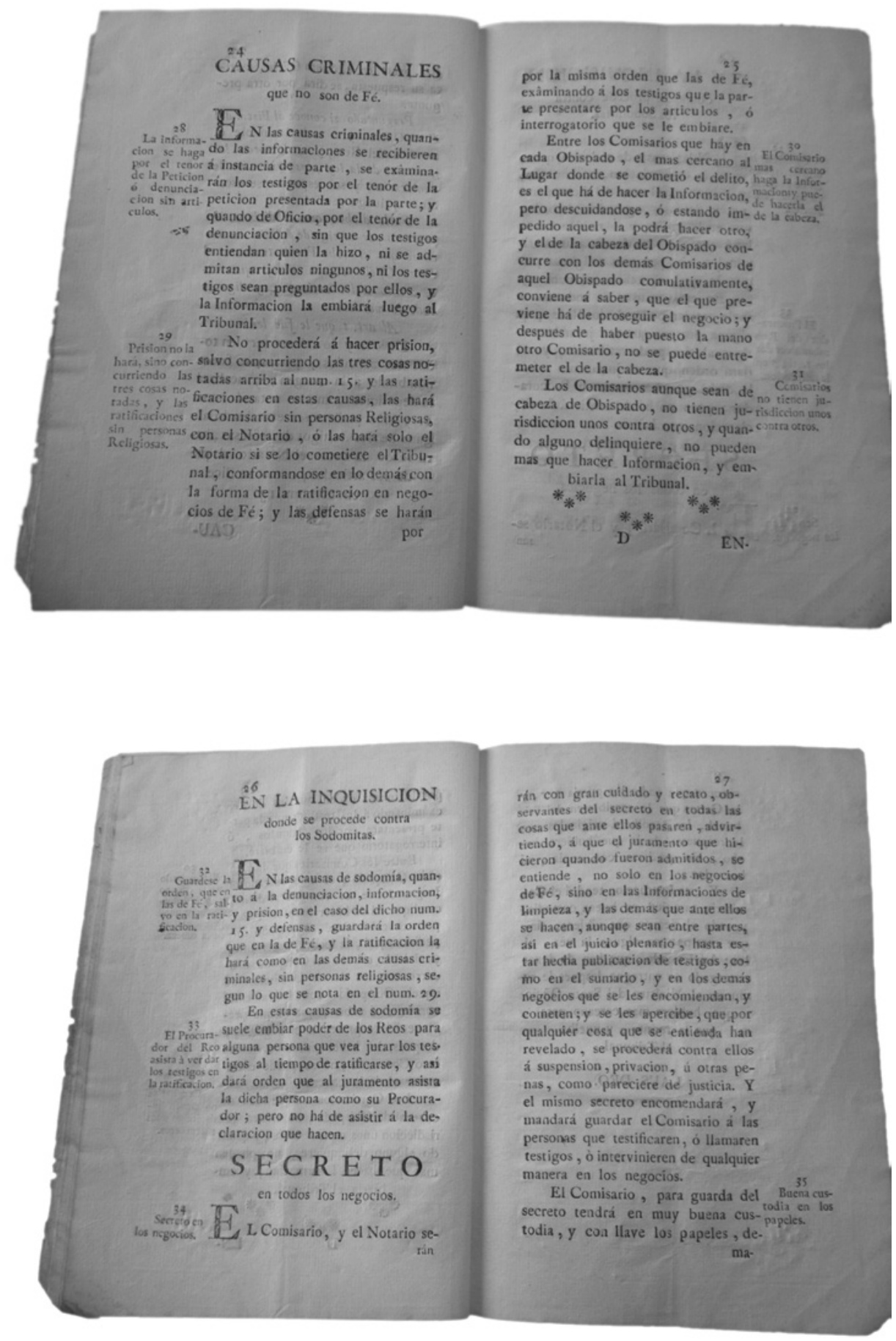
EL COMISARIO EN LAS PRIMERAS DILIGENCIAS DE INVESTIGACIÓN...

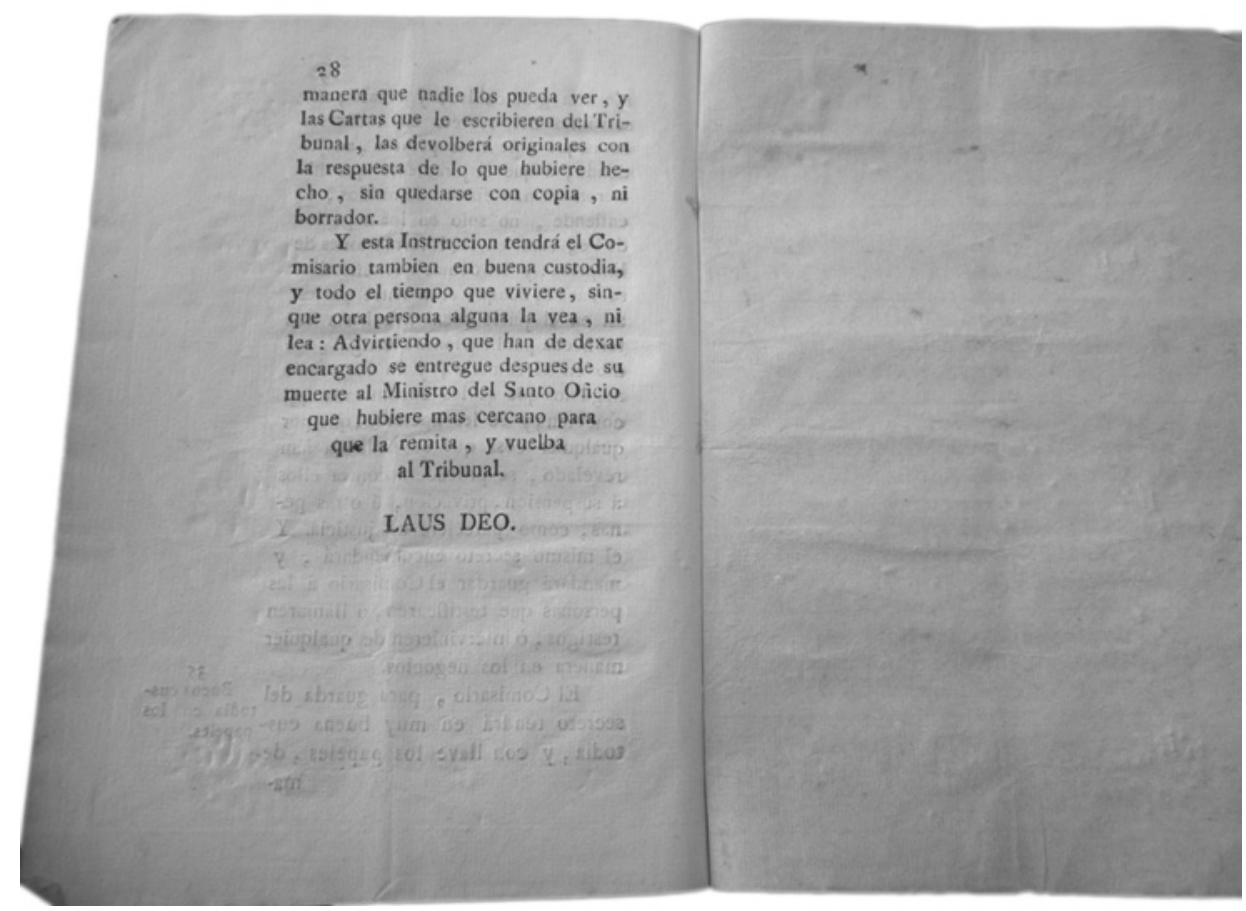

(C) UNED. Revista de Derecho UNED, núm. 16, 2015 
